\title{
Discovery of $(S)$-3'-hydroxyblebbistatin and $(S)$-3'-aminoblebbistatin: polar myosin II inhibitors with superior research tool properties
}

Sigrid Verhasselt, ${ }^{[\mathrm{a}]}$ Bart I. Roman, ${ }^{[\mathrm{a}]^{*}}$ Olivier De Wever, ${ }^{[\mathrm{b}]}$ Kristof Van Hecke, ${ }^{[\mathrm{c}]}$ Rik Van Deun, ${ }^{[c]}$ Marc E. Bracke, ${ }^{[b]}$ and Christian V. Stevens ${ }^{[a]}{ }^{*}$

[a] SynBioC Research Group, Department of Sustainable Organic Chemistry and Technology, Ghent University, Coupure Links 653, 9000 Ghent (Belgium)

*E-mail: bart1.roman@ugent.be, chris.stevens@ugent.be

[b] Laboratory of Experimental Cancer Research, Department of Radiation Oncology and Experimental Cancer Research, Ghent University, De Pintelaan 185, 9000 Ghent (Belgium)

[c] Department of Inorganic and Physical Chemistry, Ghent University, Krijgslaan 281 S3, 9000 Ghent (Belgium)

ABBREVIATIONS. $\Delta$, reflux; 2-mTHF, 2-methyltetrahydrofuran; APCI, atmospheric pressure chemical ionization; cps, counts per second; CV, column volume; DMEM, Dulbecco's modified Eagle medium; EGTA, ethylene glycol-bis( $\beta$-aminoethyl ether)- $N, N, N^{\prime}, N^{\prime}$-tetraacetic acid; N.D., not determined; s.d., standard deviation. 
ABSTRACT. In search of myosin II inhibitors with superior research tool properties, a chemical optimization campaign of the blebbistatin scaffold was conducted in this paper. $(S)$-blebbistatin is the best known small-molecule inhibitor of myosin II ATPase activity. Unfortunately, as a research tool this compound has several deficiencies: it is photolabile and (photo)toxic, has low water solubility, and its (fluorescent) precipitates interfere in (fluorescence) readouts. In view of obtaining tool compounds with improved properties, both enantiomers of a series of D-ring modified polar analogs were prepared. We identified $(S)$-3'-hydroxyblebbistatin $(S)$-2 and $(S)$-3'aminoblebbistatin $(S)-\mathbf{3}$ as two myosin II inhibitors with a 30-fold higher water solubility than (S)-blebbistatin. These molecules furthermore do not cause interference in (fluorescence) readouts. $(S)$-2 and $(S)$-3 thus are superior alternatives to $(S)$-blebbistatin as research tools to study myosin II. 


\section{INTRODUCTION}

Myosins are actin-based ATP-driven molecular motor proteins. ${ }^{1}$ They play a key role in many forms of eukaryotic motility, such as muscle contraction, cytokinesis, intracellular trafficking, phagocytosis, and cell movement. ${ }^{2-4}(S)$-blebbistatin $(S)-\mathbf{1}$ (Figure 1) is a micromolar, cellpermeable ATPase cycle inhibitor of myosin II. Its main virtue is specificity: it does not modulate myosins $\mathrm{I}, \mathrm{V}$, and $\mathrm{X}^{5}$
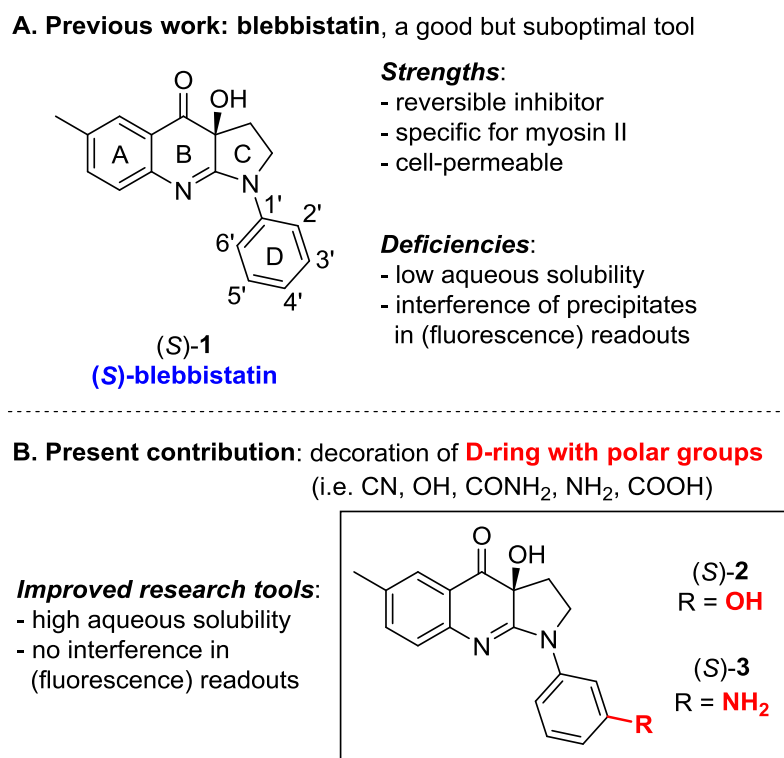

Figure 1. Overview of the state of the art and present work.

Since its discovery in $2001,{ }^{6}(S)$-blebbistatin $(S)$-1 has rapidly been embraced as a research tool: it has played a significant role in the understanding of the function of myosin II in biological processes, ${ }^{2-4}$ and has provided insight into the cellular and molecular events that drive a range of myosin II-related diseases, such as invasion in malignant disease, ${ }^{7-10}$ viral infections, ${ }^{11-13}$ bacterial infections, ${ }^{14}$ glaucoma, ${ }^{15}$ progressive renal disease, ${ }^{16}$ and methamphetamine use relapse. ${ }^{17}$ However, as is the case for other 'first-in-class' tool compounds, $(S)$-blebbistatin $(S)$-1 bears deficiencies that encumber or prohibit its use in 
sophisticated model systems: it is photolabile, ${ }^{18-23}$ (photo)toxic, ${ }^{18,21,22}$ has limited water solubility, ${ }^{23-25}$ and its (fluorescent) precipitates interfere in (fluorescence) readouts. ${ }^{26-28}$ The main objective in the present study was therefore to develop $(S)$-blebbistatin analogs with superior research tool characteristics. We hypothesized that this would require the introduction of polar functionalities on its scaffold (Figure 1): the ensuing increased aqueous solubility would eliminate assay readout issues by preventing the formation of precipitates.

Following this rationale, the novel analogs $(S)-3$ '-hydroxyblebbistatin $(S)-2$, $(S)-3$ 'aminoblebbistatin $(S)$-3, $(S)$-3'-cyanoblebbistatin $(S)-\mathbf{1 3},(S)-3$ '-carbamoylblebbistatin $(S)-\mathbf{1 6}$, and $(S)-3$ '-carboxyblebbistatin $(S)-\mathbf{1 7}$, and their $R$-enantiomers (negative controls), ${ }^{29}$ were synthesized. The myosin II inhibitory activity of these compounds was evaluated in a biochemical assay (i.e. an ATPase assay). We furthermore discuss the physicochemical properties of these molecules, including solubility and fluorescence data. During the final preparation of this manuscript, a paper on a single polar blebbistatin derivative with improved physicochemical properties was published by Varkúti et al. ${ }^{30}$ Our study provides broader context by the exploration of an elaborate family of polar analogs. We furthermore provide detailed synthetic protocols and analytical data, in order to facilitate the broad use of our molecules as research tool compounds to study myosin II.

\section{RESULTS AND DISCUSSION}

\section{Chemistry}

Polar blebbistatin analogs $(S)$ - and $(R)-\mathbf{2 , 3 , 1 3 , 1 6 , 1 7}$ were prepared after select adaptation of a route that has proven successful for $(S)$-blebbistatin $(S)-1 .^{20}$ The syntheses commenced with arylations of 2-pyrrolidinone (5) in very good yields (Scheme 1). 


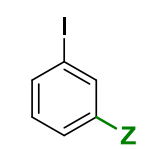

4a $(\mathrm{Z}=\mathrm{H})$

$4 \mathrm{~b}(Z=$ OAllyl $)$

4c $\left(Z=N(\text { Allyl })_{2}\right)$

$4 d(Z=C N)$

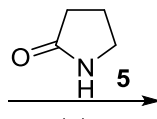

(a)

$$
\begin{aligned}
& \mathbf{6 a}(Z=H)(89 \%) \\
& \mathbf{6 b}(Z=O A l l y l)(75 \%) \\
& \mathbf{6 c}\left(Z=N(A l l y l)_{2}\right)(79 \%) \\
& \mathbf{6 d}(Z=C N)(88 \%)
\end{aligned}
$$

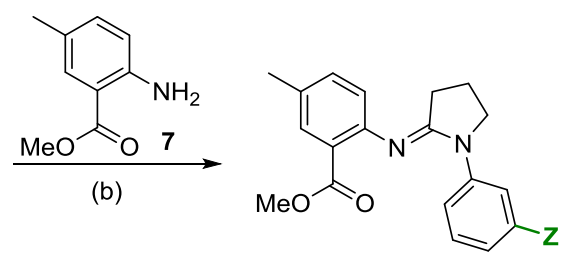

8a $(\mathrm{Z}=\mathrm{H})(78 \%)$

8b (Z = OAllyl) $(50 \%)$

$8 \mathrm{c}\left(Z=\mathrm{N}(\mathrm{Allyl})_{2}\right)(29 \%)$

8d $(Z=C N)(30 \%)$

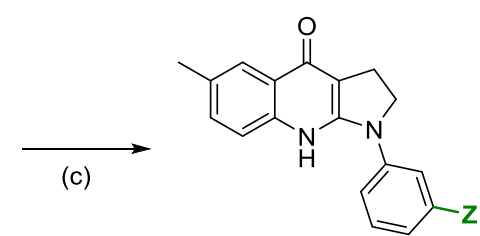

9a $(\mathrm{Z}=\mathrm{H})(98 \%)$

9b (Z = OAllyl) (82\%)

9c $\left(Z=N(A l l y l)_{2}\right)(62 \%)$

9d $(Z=C N)(86 \%)$

Scheme 1. Synthesis of quinolones 9a-d. Reagents and conditions: (a) CuI, 5, tris(3,5-dimethyl1H-pyrazol-1-yl)methane, $\mathrm{K}_{3} \mathrm{PO}_{4}, 1$,4-dioxane, reflux, 24-72 h; (b) 1) $\mathrm{POCl}_{3}, \mathrm{CH}_{2} \mathrm{Cl}_{2}, \mathrm{rt}, 24 \mathrm{~h}$, 2) $7, \mathrm{CH}_{2} \mathrm{Cl}_{2}, 35^{\circ} \mathrm{C}, 24 \mathrm{~h}$; (c) LiHMDS, THF, $0{ }^{\circ} \mathrm{C}, 1 \mathrm{~h}$.

The synthesis of amidine 8a, starting from pyrrolidinone $\mathbf{6 a}$ and amine 7, was performed in the presence of phosphorus oxychloride via a modified procedure of Lucas-Lopez et al. ${ }^{20}$ The amount of phosphorus oxychloride was doubled and the reaction time for the formation of the chloroiminium intermediate was increased from $3 \mathrm{~h}$ to $24 \mathrm{~h}$. In this way, a conversion of $95 \%$ was obtained (Table 1). Isolation of the amidine out of the crude reaction mixture via acid-base extraction, as reported in the procedure of Lucas-Lopez et al., ${ }^{20}$ proved difficult and afforded amidine $8 \mathbf{a}$ in $2 \%$ yield. This compound was isolated in $78 \%$ yield when the same crude reaction mixture was purified by reversed phase automated flash chromatography. This procedure affords amidine 8a was obtained in a much higher yield than the previously reported strategies. With these conditions in hand, amidines $\mathbf{8 b}-\mathbf{d}$ were synthesized in the same manner (Scheme 1). The presence of (mild) electron withdrawing groups (e.g. protonated amino group (formed under the acidic conditions used) in $\mathbf{6 c}$, cyano group in $\mathbf{6 d}$ ) in pyrrolidinones $\mathbf{6 c - d}$ hampered the nucleophilic character of the aryl amide, leading to rather high amounts of unreacted starting material. A similar observation was made for the electron donating allyloxy group in $\mathbf{6 b}$. Attempts to improve this transformation, using alternative reagents or starting materials, and/or by the addition of base, were unsuccessful (Table 1). 
Table 1. Optimization of the synthesis of amidines 8a-d.

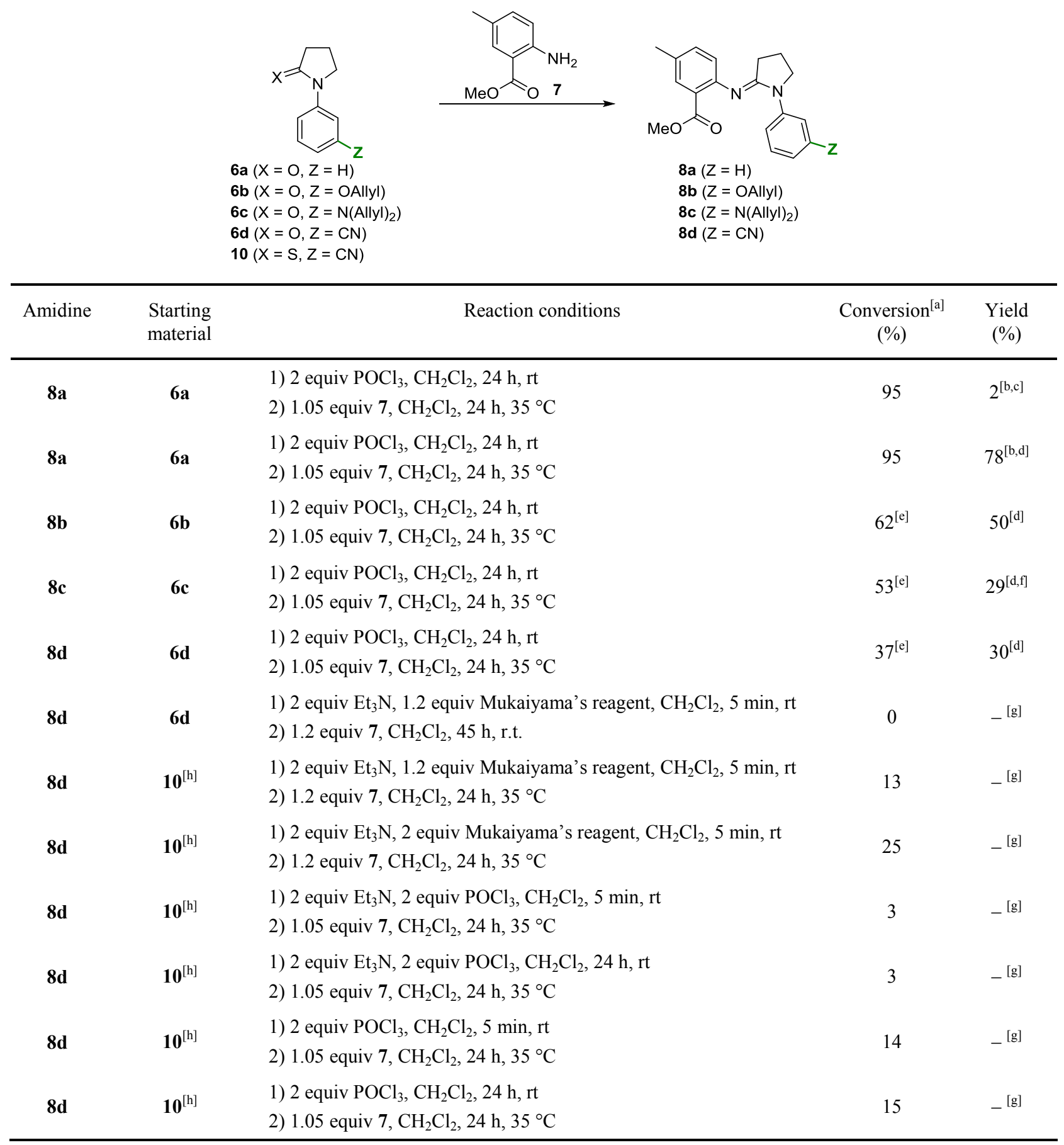

[a] ${ }^{1} \mathrm{H}$ NMR. [b] Previously prepared by Lucas-Lopez et al. in $41 \%$ yield: 1) 1.1 equiv 6a, 1 equiv $\mathrm{POCl}_{3}, \mathrm{CH}_{2} \mathrm{Cl}_{2}, 3 \mathrm{~h}, \mathrm{rt}$; 2) 1 equiv $7, \mathrm{CH}_{2} \mathrm{Cl}_{2}, 16 \mathrm{~h}, 35^{\circ} \mathrm{C} .{ }^{20}$ [c] Purified via acid-base extraction. [d] Purified via reversed phase automated flash chromatography. [e] Unreacted starting material was fully recovered. [f] 85\% purity. [g] Not isolated. [h] Pyrrolidinethione 10 was prepared from pyrrolidinone $\mathbf{6 d}$ and Lawesson's reagent. ${ }^{31}$ When excess Lawesson's reagent (more than 0.5 equivalents) and/or prolonged reaction times (more than 30 minutes) were used at 
elevated temperatures $\left(70^{\circ} \mathrm{C}\right)$, thionation of the nitrile functionality in pyrrolidinethione $\mathbf{1 0}$ also occurred.

Intramolecular cyclization gave quinolones 9a-d in good to excellent yields (Scheme 1). The ensuing asymmetric $\alpha$-hydroxylation (Scheme 2) was carried out using Davis' oxaziridine methodology. In all cases, quinolones $\mathbf{9 a - d}$ were completely converted to $\alpha$-hydroxy ketones $(S)$ - and $(R)-\mathbf{1 , 1 1 - 1 3}$, but isolated yields varied. A single recrystallization from $\mathrm{CH}_{3} \mathrm{CN}$ or $\mathrm{EtOH}$ resulted in highly optically enriched $(S)$ - and $(R)-\mathbf{1 , 1 1}$ and $(S)$ - and $(R)-\mathbf{1 2}$, respectively.

Intermediates 11 and $\mathbf{1 2}$ were deprotected in high yields (Scheme 3) without affecting the blebbistatin scaffold. Nitriles $(S)$ - and $(R)$-13 were selectively hydrolyzed to amides $(S)$ - and $(R)$ 16, which were successfully optically enriched by recrystallization from EtOH. Amides $(S)$ - and $(R)$-16 were further converted into carboxylic acids $(S)$ - and $(R)$-17. Isolation of these acids from the crude reaction mixture proved tedious, due to their polar and zwitterionic nature. $(S)-\mathbf{1 7}$ was only recovered in low yield by preparative TLC. Conversely, a quick work-up of the crude mixture afforded $(R)-\mathbf{1 7}$ in good yield and similar purity as obtained for $(S)$-17 after preparative TLC. Finally, the absolute configuration of $(S)-2$ and $(R)-2$ was determined by X-ray analysis (see the Supporting Information), and this confirms the formation of $(S)$ - and $(R)-\alpha$-hydroxy ketones using Davis' oxaziridines 14 and 15, respectively (Scheme 2). 

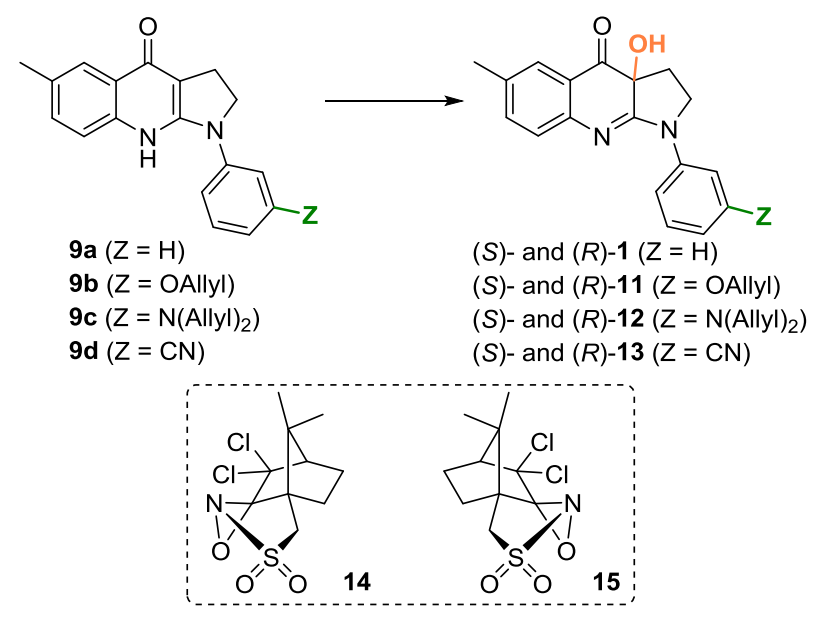

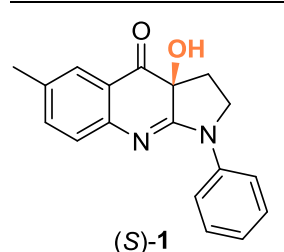

$(85 \% \text {, ee } 75 \%)^{[a]}$

$(37 \%, \text { ee }>99 \%)^{[a, b]}$

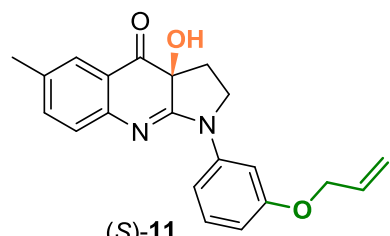

$(68 \% \text {, ee } 78 \%)^{[a]}$

$(19 \% \text {, ee }>99 \%)^{[a, b]}$
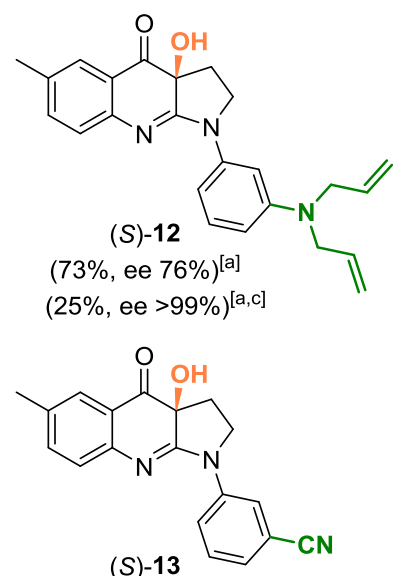

$(97 \% \text {, ee } 83 \%)^{[a]}$

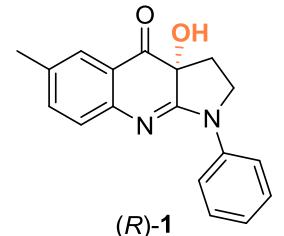

$(63 \% \text {, ee } 75 \%)^{[\mathrm{a}]}$

$(20 \% \text {, ee } 99 \%)^{[a, b]}$

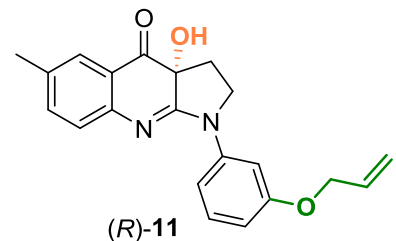

$(77 \% \text {, ee } 79 \%)^{[\mathrm{a}]}$

$(36 \% \text {, ee }>99 \%)^{[a, b]}$
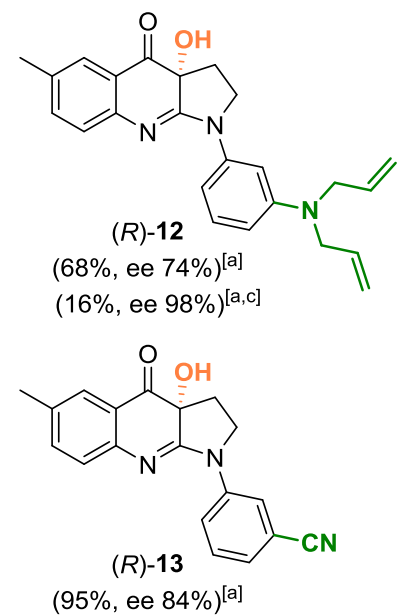

Scheme 2. Asymmetric $\alpha$-hydroxylation of quinolones 9a-d. Reagents and conditions: 1) LiHMDS, THF, $\left.-78^{\circ} \mathrm{C}, 30 \mathrm{~min}, 2\right) \mathbf{1 4}$ (for $(S)$-1,11-13) or $\mathbf{1 5}$ (for $(R)-\mathbf{1 , 1 1 - 1 3}$ ), THF, $-15^{\circ} \mathrm{C}$, $16 \mathrm{~h}$. [a] Determination of ee via chiral HPLC analysis. [b] After recrystallization from $\mathrm{CH}_{3} \mathrm{CN}$. [c] After recrystallization from EtOH. 


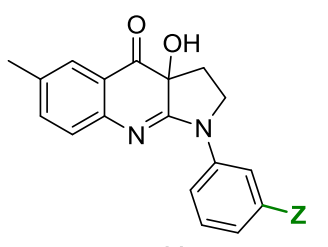

(S)- and (R)-11 (Z = OAllyl)

$(S)$ - and $(R)-12(Z=\mathrm{N}($ Allyl $) 2)$

$(S)$ - and $(R)-13(Z=C N)$ (a) (for 11), (b) (for 12) or (c) (for 13)

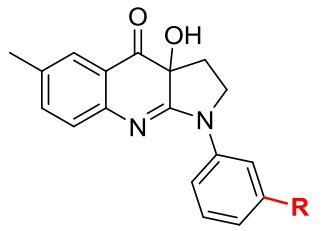

$(S)$ - and $(R)-2(\mathrm{R}=\mathrm{OH})$

(S)- and $(R)-3\left(\mathrm{R}=\mathrm{NH}_{2}\right)$

$(S)$ - and $(R)-16\left(\mathrm{R}=\mathrm{CONH}_{2}\right)$

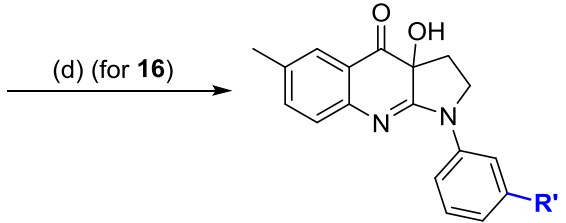

$(S)$ - and $(R)-17\left(\mathrm{R}^{\prime}=\mathrm{COOH}\right)$

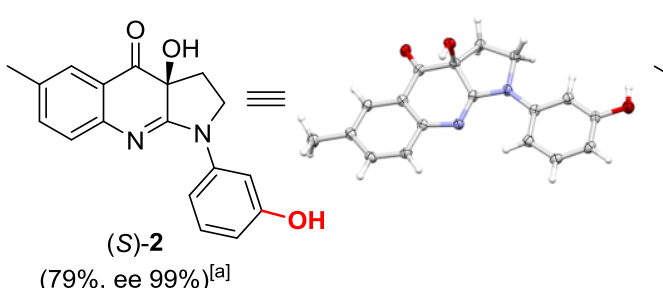

$(79 \% \text {, ee } 99 \%)^{[a]}$

$(76 \%, \text { ee }>99 \%)^{[\mathrm{a}]}$
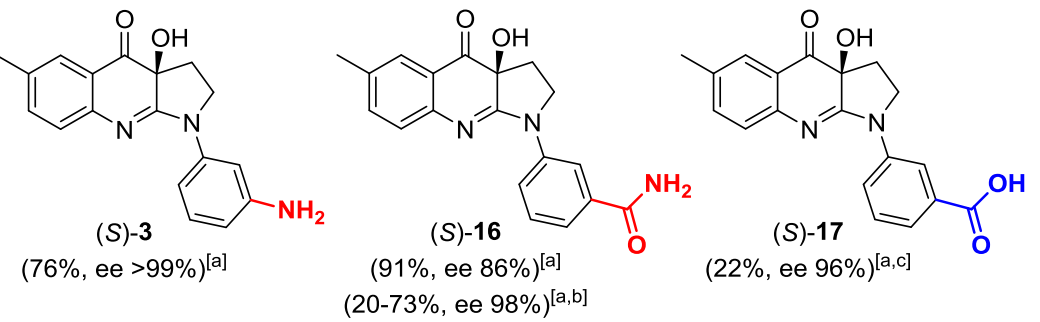

$(22 \% \text {, ee } 96 \%)^{[a, c]}$
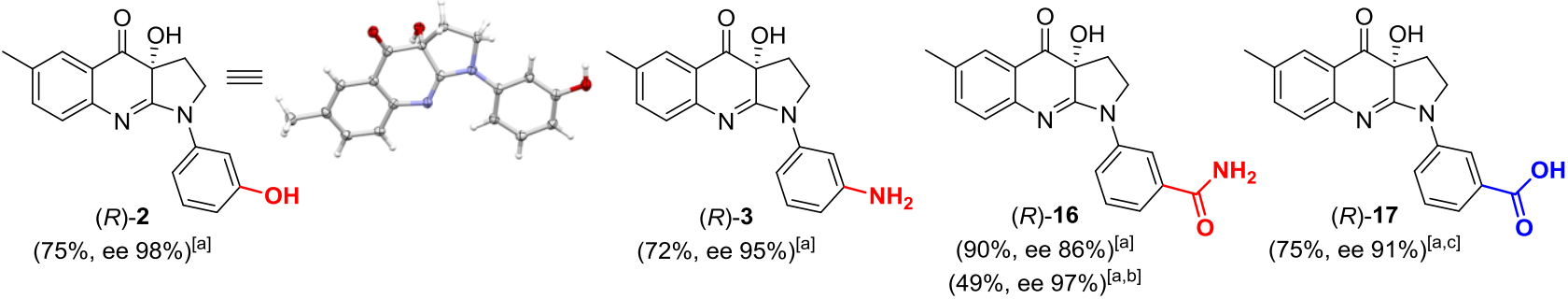

Scheme 3. Deprotection of $(S)$ - and $(R)$-11-13: formation of polar blebbistatin analogs $(S)$ - and (R)-2,3,16,17. Reagents and conditions: (a) $\mathrm{Pd}\left(\mathrm{PPh}_{3}\right)_{4}, \mathrm{~K}_{2} \mathrm{CO}_{3}, \mathrm{MeOH}, 50{ }^{\circ} \mathrm{C}, 1 \mathrm{~h}$; (b) N,N'dimethylbarbituric acid, $\mathrm{Pd}\left(\mathrm{PPh}_{3}\right)_{4}, \mathrm{CH}_{2} \mathrm{Cl}_{2}$, reflux, $1 \mathrm{~h}$; (c) $\mathrm{Et}_{2} \mathrm{NOH}, \mathrm{CH}_{2} \mathrm{Cl}_{2}$, reflux, $48 \mathrm{~h}$; (d) $\mathrm{H}_{2} \mathrm{SO}_{4}, \mathrm{H}_{2} \mathrm{O}, 70{ }^{\circ} \mathrm{C}, 14 \mathrm{~h}$. [a] Determination of ee via chiral HPLC analysis. [b] After recrystallization from EtOH. [c] Determination of ee via chiral HPLC analysis of corresponding methyl ester.

The key steps in the synthesis of blebbistatin derivatives 2, 3, 13, 16 and 17 were the successful introduction and removal of a suitable masked polar group. Of the evaluated alternatives (OMEM, OAlloc, OAllyl, NHMEM, NHAlloc, N(Allyl) $)_{2}$ CN), only the allyl protecting group and cyano function proved appropriate for the preparation of blebbistatin analogs 2,3 and $\mathbf{1 3}, \mathbf{1 6}, \mathbf{1 7}$, respectively. Finally, enantiopurity of both enantiomers of all newly synthesized blebbistatin derivatives $\mathbf{2 , 3 , 1 1 - 1 3 , 1 6 , 1 7}$ was determined via chiral HPLC analysis. Unfortunately, this feature is often neglected in literature. ${ }^{24,30}$ Knowledge of the enantiopurity of $(S)$-blebbistatin or its derivatives is highly important when using these molecules to modulate 
myosin II function in biochemical or biological experiments, as the $(R)$-enantiomers display no affinity for myosin II (vide infra).

\section{Biochemical evaluation}

The myosin II inhibitory properties of both enantiomers of compounds 1-3, 13, 16 and 17 were evaluated in vitro in a steady state ATPase assay using rabbit skeletal muscle myosin II. The half-maximum inhibitory concentrations $\left(\mathrm{IC}_{50}\right)$ of $(S)$-3'-hydroxyblebbistatin $(S)$-2 and $(S)$ 3'-aminoblebbistatin (S)-3 in the ATPase assay (Figure 2, Table 2) lie somewhat higher, but still in the same order of magnitude as that of parent compound (S)-1. $(S)$-3'-cyanoblebbistatin $(S)$-13 proved less potent. The maximal extent of inhibition is the same for all four compounds at high concentrations (50-100 $\mu \mathrm{M})$. (S)-3'-carbamoylblebbistatin $(S)$-16 and $(S)$-3'-carboxyblebbistatin (S)-17, on the other hand, were ineffective at concentrations up to $100 \mu \mathrm{M}$. As expected, ${ }^{29}$ all $(R)$-enantiomers lacked efficacy.

The data generated from the ATPase assay yield useful SAR information. They highlight that the $(S)$-configuration is essential for activity, confirming a similar binding mode for $(S)$-3'hydroxyblebbistatin $(S)$-2, $(S)$-3'-aminoblebbistatin $(S)$-3 and $(S)$-3'-cyanoblebbistatin $(S)$-13 as for $(S)-1$. The data also reveal that small hydrophilic groups in the meta-position of ring D can be accommodated, but do not influence potency in an appreciable manner. Large polar groups are not well tolerated. The kinetics of the chemo-mechanical cycle of myosin may play an important role in the observed ligand discrimination. Preliminary in silico studies (data not shown) suggest that steric and temporal restrictions imposed by the path(s) leading toward the binding site may be a possible reason behind this observation. A full report of these investigations will be disclosed in due course. 
A

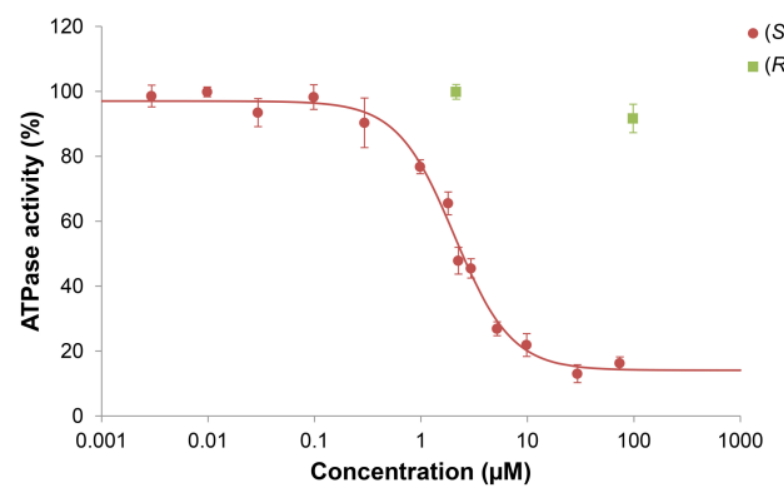

C

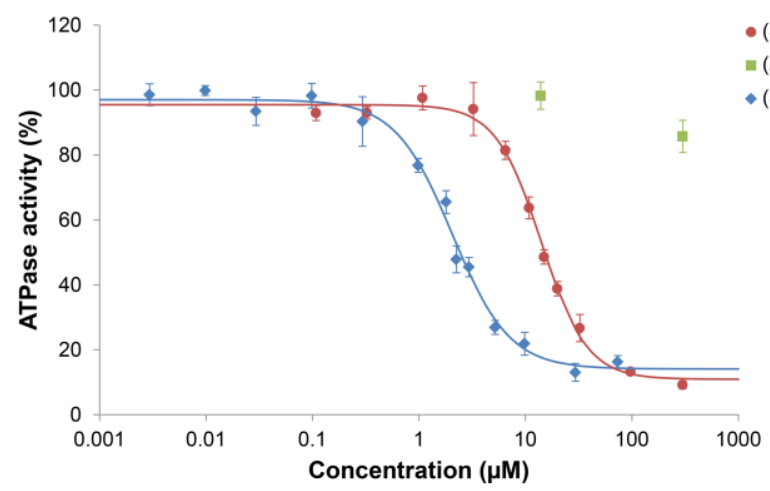

$\mathrm{E}$

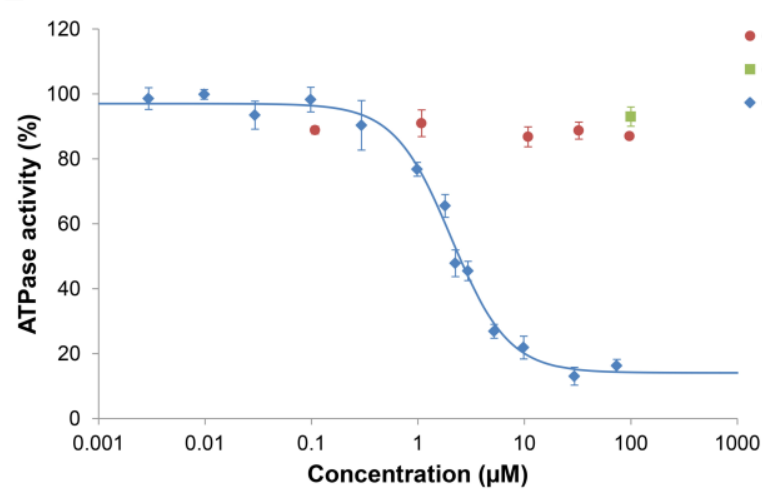

B

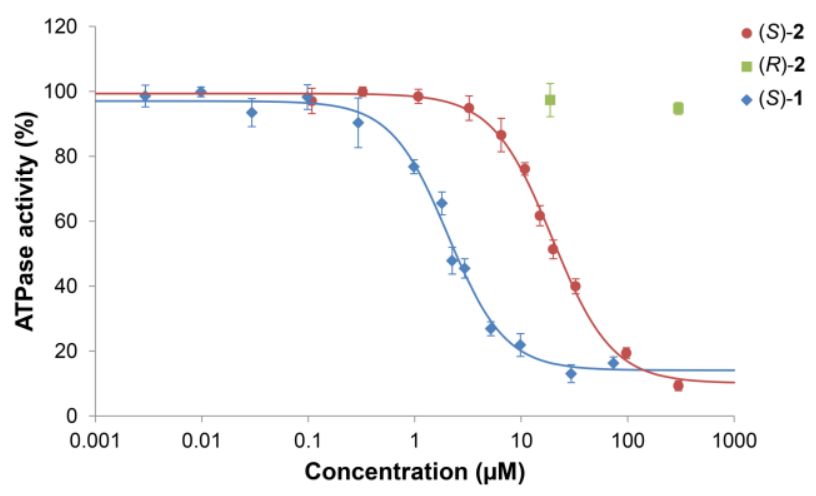

D

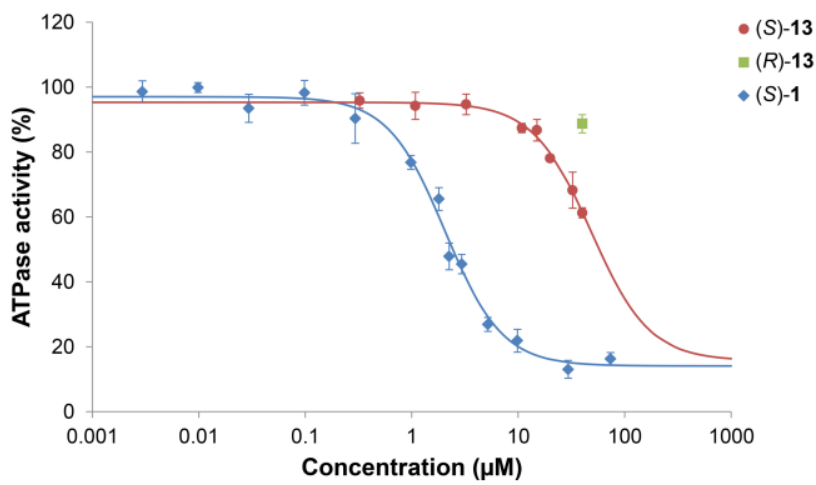

$\mathrm{F}$

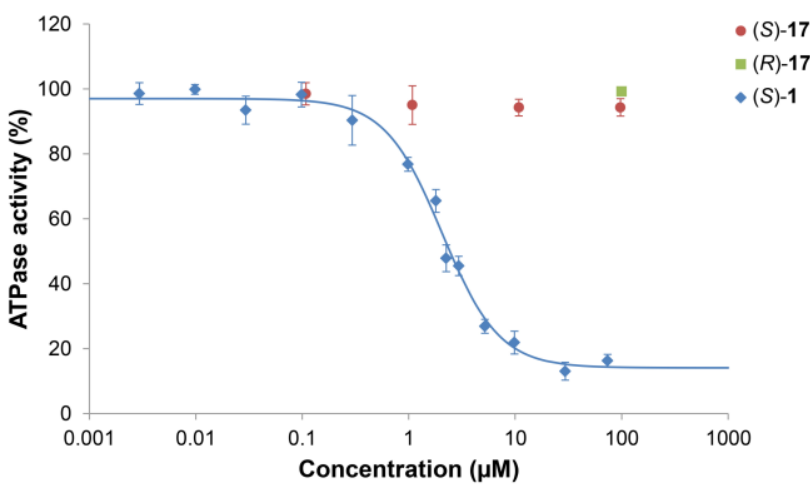

Figure 2. Biochemical evaluation of the myosin II inhibitory properties of both enantiomers of compounds 1-3, 13, 16 and 17, evaluated in an ATPase assay with rabbit skeletal muscle myosin II. Examples of dose-response curves and 4-parameter logistic curve fitting obtained for (A) $(S)$ blebbistatin $(S)$-1 and $(R)$-blebbistatin $(R)$-1, (B) $(S)$-3'-hydroxyblebbistatin $(S)$-2 and $(R)$-3'hydroxyblebbistatin $(R)$-2, (C) $(S)$-3'-aminoblebbistatin $(S)$-3 and $(R)$-3' -aminoblebbistatin $(R)$ 3, (D) (S)-3'-cyanoblebbistatin (S)-13 and (R)-3'-cyanoblebbistatin (R)-13, (E) (S)-3'carbamoylblebbistatin (S)-16 and (R)-3'-carbamoylblebbistatin (R)-16, and (F) (S)-3'carboxyblebbistatin $(S)$-17 and $(R)$-3'-carboxyblebbistatin $(R)$-17. Data points represent the means \pm s.d. of at least three samples $(\mathrm{N}=1)$. Concentrations higher than $40 \mu \mathrm{M}$ caused $(S)-3$ 'cyanoblebbistatin $(S)$-13 to precipitate in the assay buffer (Figure S72 in the Supporting 
Information), so the relative ATPase activity of $(S)$-blebbistatin $(S)$-1 at a concentration of $32.5 \mu \mathrm{M}$ was used to set the lower asymptote of the fitted curve.

Table 2. Biochemical and physicochemical evaluation of compounds $(S)$ - and $(R)-\mathbf{1}-\mathbf{3}, \mathbf{1 3}, \mathbf{1 6}$, and 17: half-maximum inhibitory concentrations $\left(\mathrm{IC}_{50}\right)$ for the steady state ATPase activity of rabbit skeletal muscle myosin II, and solubility data in PBS pH 7.4 buffer.

\begin{tabular}{|c|c|c|c|c|}
\hline Compound & $\begin{array}{l}\mathrm{IC}_{50}[\mathrm{a}] \\
(\mu \mathrm{M})\end{array}$ & $\begin{array}{l}\text { Solubility }^{[b]} \\
(\mu \mathrm{M})\end{array}$ & Compound & $\begin{array}{l}\mathrm{IC}_{50}{ }^{[\mathrm{a}]} \\
(\mu \mathrm{M})\end{array}$ \\
\hline$(S)-1$ & $2.16 \pm 0.14$ & $6.18 \pm 0.08$ & $(R)-1$ & $>100^{[\mathrm{c}]}$ \\
\hline$(S)-2$ & $19.3 \pm 0.5$ & $193 \pm 1$ & $(R)-2$ & $>300^{[\mathrm{d}]}$ \\
\hline$(S)-3$ & $14.1 \pm 0.1$ & $186 \pm 9$ & $(R)-3$ & $>300^{[\mathrm{d}]}$ \\
\hline$(S)-13$ & $48.5 \pm 0.1$ & N.D. ${ }^{[\mathrm{e}]}$ & $(R)-13$ & $>40^{[\mathrm{f}]}$ \\
\hline$(S)-16$ & $>100^{[\mathrm{c}]}$ & $86.3 \pm 6.7$ & $(R)-16$ & $>100^{[\mathrm{c}]}$ \\
\hline$(S)-17$ & $>100^{[\mathrm{c}]}$ & $>200^{[\mathrm{g}]}$ & $(R)-17$ & $>100^{[\mathrm{c}]}$ \\
\hline
\end{tabular}

[a] Data represent mean \pm s.d. of two independent experiments $(1.6 \%$ DMSO). [b] Data represent mean \pm s.d. of two independent experiments ( $2 \%$ DMSO). [c,d,f,g] Highest compound concentrations used were 100, 300, 40, and $200 \mu \mathrm{M}$, respectively. [e] Not determined. [f] Concentrations $>40 \mu \mathrm{M}$ resulted in compound precipitation in the assay buffer (Figure S73 in the Supporting Information).

\section{Physicochemical evaluation}

A major issue with $(S)$-blebbistatin $(S)-\mathbf{1}$ is its limited solubility in aqueous media. Since high (S)-1 concentrations $(50-100 \mu \mathrm{M})$ are typically required to halt myosin II dependent cellular processes, experiments are de facto carried out in oversaturated solutions. ${ }^{5}$ This creates uncertainty about actual assay concentrations and, as will be shown below, can produce interfering precipitates. We found that the solubility of $(S)$-blebbistatin $(S)-\mathbf{1}$ in PBS pH 7.4 buffer (Table 2) is $6.18 \pm 0.08 \mu \mathrm{M}$ at $2 \%(\mathrm{v} / \mathrm{v}) \mathrm{DMSO}$. As anticipated, the solubility of the newly synthesized alcohol, amine, amide and carboxylic acid derivatives under the same conditions proved significantly higher. (S)-3'-cyanoblebbistatin $(S)$-13 was not evaluated, since precipitation was noted above $40 \mu \mathrm{M}$ in the ATPase assay. Most importantly, the solubility of 
the most potent derivatives, $(S)-3$ '-hydroxyblebbistatin $(S)$-2 and $(S)$-3'-aminoblebbistatin $(S)$-3, is over 30 times higher than that of $(S)$-blebbistatin $(S)-\mathbf{1}$.

A second, even more severe limitation of $(S)$-blebbistatin $(S)$-1 is its interference when using fluorescence as a readout. Two of the most important experiments in this context are cardiac optical mapping, ${ }^{26,32}$ and the study of myosin II function in the cell. Both are routinely conducted using $(S)$-blebbistatin $(S)$-1 as a tool to inhibit myosin II. In the former experiment, calcium concentrations are measured using fluorescent $\mathrm{Ca}^{2+}$ indicators (Fluo-3, Fluo-4, Fluo-5F). When studying myosin II function in the cell, fluorescence microscopy with GFP-labeled myosin II is often used. In both experimental setups, the use of $(S)$-blebbistatin $(S)$-1 is accompanied with fluorescence interference upon excitation in the $488 \mathrm{~nm}$ region. It is often assumed that $(S)$ blebbistatin (S)-1 solutions are highly fluorescent and thereby cause this interference..$^{20,23}$ However, during our own prior biological work in media containing high $(S)$-blebbistatin $(S)$-1 concentrations, we had realized that $(S)$-blebbistatin $(S)$-1 crystals, rather than $(S)$-blebbistatin (S)-1 in solution, were the actual cause of the observed interference. We therefore hypothesized that the use of more water soluble blebbistatin analogs would eliminate fluorescence interference. To test this assumption, we exposed MCF- $7 / 6$ breast carcinoma cells, a commonly used cell line in our laboratories, ${ }^{7}$ to low and high concentrations of $(S)$-blebbistatin $(S)-\mathbf{1}$ and imaged after $24 \mathrm{~h}$ of incubation (Figure 3). At low (S)-blebbistatin $(S)$-1 concentrations (Figures 3A and 3B), no fluorescence upon $488 \mathrm{~nm}$ excitation was observed. Conversely, at high $(S)$ blebbistatin (S)-1 concentrations (Figures 3C and 3D), fluorescent precipitates were clearly visible. When repeating the experiment with the most potent polar derivatives, $(S)$-3'hydroxyblebbistatin (S)-2 (Figure S75 in the Supporting Information) and (S)-3'- 
aminoblebbistatin (S)-3 (Figures 3E and 3F, and Figure S74 in the Supporting Information), no fluorescence was detected.
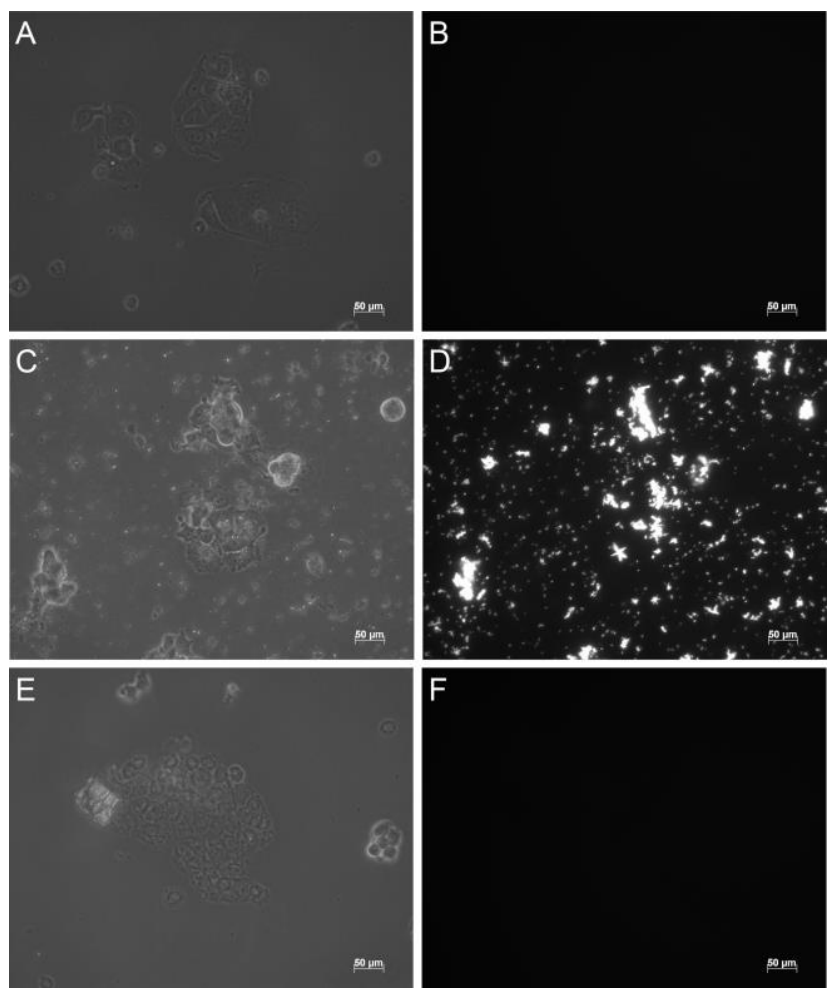

Figure 3. Low solubility of $(S)$-blebbistatin $(S)$-1 results in precipitates that interfere during fluorescence imaging when applied at high concentrations. Fluorescence imaging of MCF-7/6 breast carcinoma cells treated with $(S)$-blebbistatin $(S)$-1 and $(S)$-3'-aminoblebbistatin $(S)$-3. (A) Brightfield and (B) fluorescence image (488 nm excitation) of treatment with $5 \mu \mathrm{M}(S)$ blebbistatin (S)-1. (C) Brightfield and (D) fluorescence image (488 nm excitation) of treatment with $50 \mu \mathrm{M}(S)$-blebbistatin (S)-1. (E) Brightfield and (F) fluorescence image (488 $\mathrm{nm}$ excitation) of treatment with $50 \mu \mathrm{M}(S)-3$ '-aminoblebbistatin $(S)$-3. Exposure time in B, D, and F is equal. Scale bar, $50 \mu \mathrm{m}$.

As $(S)$-blebbistatin $(S)$-1, $(S)$-3'-hydroxyblebbistatin $(S)$-2 and $(S)$-3'-aminoblebbistatin $(S)$-3 show similar, weak, fluorescence upon $488 \mathrm{~nm}$ excitation (Figure 4), these observations confirm that the described fluorescence issues of $(S)$-blebbistatin $(S)$-1 are due to its low aqueous solubility and the resulting formation of precipitates. $(S)-3$ '-hydroxyblebbistatin $(S)-2$ and $(S)$-3'- 
aminoblebbistatin $(S)$-3 are therefore superior tools for cardiac optical mapping and myosin II studies.
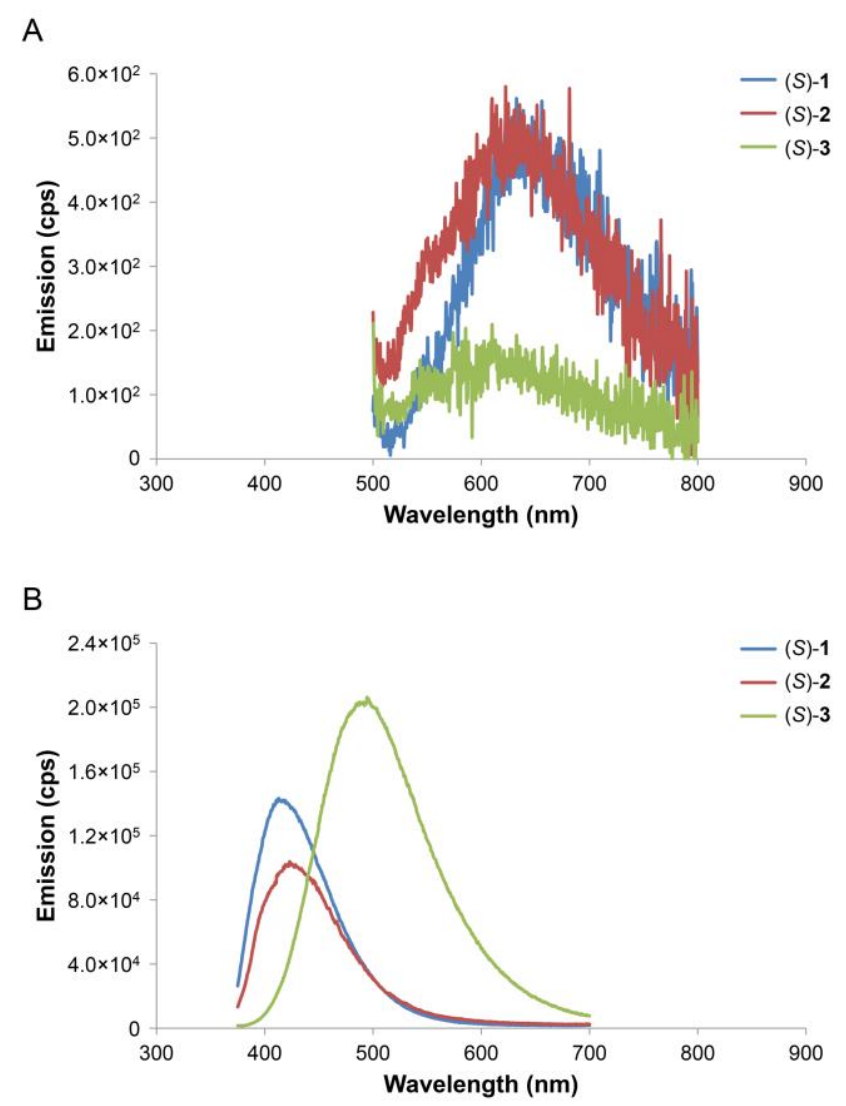

Figure 4. Fluorescent properties of $(S)$-blebbistatin $(S)$-1, $(S)$-3'-hydroxyblebbistatin $(S)-2$ and $(S)$-3'-aminoblebbistatin $(S)$-3. Emission spectra upon excitation at a wavelength of (A) $488 \mathrm{~nm}$ and (B) $365 \mathrm{~nm}$.

\section{CONCLUSIONS}

Both enantiomers of a series of polar blebbistatin analogs (2, 3, 13, 16 and 17) were synthesized in search of myosin II inhibitors with enhanced physicochemical properties and superior research tool characteristics as compared to $(S)$-blebbistatin $(S)$-1. The most important steps in their preparation consisted of (i) introduction of a suitable masked polar group in the beginning of the sequence (i.e. an allyl protecting group and cyano function for $\mathbf{2 , 3}$ and $\mathbf{1 3 , 1 6 , 1 7}$ 
respectively), (ii) an optimized synthesis and purification of the amidine intermediates and (iii) removal of the protecting group at the end of the pathway without affecting the blebbistatin scaffold. The enantiopurity of both enantiomers of these newly synthesized blebbistatin derivatives was confirmed. All $(R)$-enantiomers lacked myosin II inhibitory properties. This highlights the importance of a correct assessment of the enantiopurity of $(S)$-blebbistatin (derivatives) in terms of their use as myosin II inhibitors. Our biochemical and physicochemical evaluation demonstrated that both $(S)$-3'-hydroxyblebbistatin $(S)$-2 and $(S)$-3'-aminoblebbistatin (S)-3 combine good myosin II inhibitory properties with a 30 times higher aqueous solubility than $(S)$-blebbistatin $(S)$-1. These polar analogs moreover do not show interference in fluorescence readouts. Given these virtues, (S)-3'-hydroxyblebbistatin $(S)$-2 and $(S)$-3'aminoblebbistatin $(S)$-3 can be considered superior research tool molecules for the study of myosin II.

\section{MATERIALS AND METHODS}

\section{Chemistry}

The synthesis of compounds $\mathbf{1 - 3}, \mathbf{1 1 - 1 3}, \mathbf{1 6}$ and $\mathbf{1 7}$ is provided below. The purity of all final compounds was $95 \%$ or higher, as determined by LC-MS analysis. The synthesis of compounds 9a-d is detailed in the Supporting Information.

\subsection{General}

Dichloromethane was dried by heating under reflux over $\mathrm{CaH}_{2}$ and distilled under an atmosphere of nitrogen. Tetrahydrofuran was dried by heating under reflux with sodium/benzophenone under a nitrogen atmosphere and collected by distillation. Dry 1,4-dioxane and dry methanol were purchased from Sigma-Aldrich and Acros Organics, 
respectively. Reagents were purchased at the highest commercial quality and were used as received without further purification.

Yields refer to chromatographically and spectroscopically ( ${ }^{1} \mathrm{H}$ NMR) homogeneous material, unless otherwise stated.

Reactions were monitored on an Agilent 1200 series HPLC system fitted with an Ascentis ${ }^{\circledR}$ Express C18-column (2.7 $\mu \mathrm{m}$ particle size, $4.6 \mathrm{~mm}$ internal diameter), using acetonitrile/water (5 $\mathrm{mM} \mathrm{NH}_{4} \mathrm{OAc}$ ) as eluent. Low-resolution mass spectra were recorded on an Agilent 1100 series VL mass spectrometer (ESI, $70 \mathrm{eV}$ ). High-resolution mass spectra (HRMS) were recorded using an Agilent Technologies 6210 series time-of-flight (TOF) mass spectrometer equipped with an ESI/APCI-multimode source. Thin layer chromatography (TLC) was carried out on $0.25 \mathrm{~mm}$ Merck silica plates (60 F254) and spots were visualized by UV light (254 nm). Flash column chromatography was performed on an automated Reveleris ${ }^{\circledR}$ X2 flash chromatography system, using Reveleris ${ }^{\circledR}$ C18 or Reveleris ${ }^{\circledR}$ silica cartridges. Melting points were determined using a Wagner \& Munz WME Heizbank Kofler bench.

NMR spectra were recorded on a Bruker Avance III instrument. ${ }^{1} \mathrm{H}$ NMR (400 MHz) chemical shifts are recorded in $\mathrm{CDCl}_{3}$ or $\mathrm{DMSO}-\mathrm{d}_{6}$, reported in $\mathrm{ppm}$ and measured relative to tetramethylsilane or the residual undeuterated solvent as the internal reference, respectively. ${ }^{13} \mathrm{C}$ NMR $(100.6 \mathrm{MHz})$ chemical shifts are reported in ppm and were measured relative to the residual undeuterated solvent as the internal reference. The following abbreviations were used to explain NMR peak multiplicities: $\mathrm{s}=$ singlet, $\mathrm{d}=$ doublet, $\mathrm{t}=$ triplet, $\mathrm{q}=$ quartet, $\mathrm{p}=$ pentet, $\mathrm{m}=$ multiplet, $b r=$ broad.

The enantiomeric excess (ee) of chiral compounds was determined via chiral HPLC analysis using a Daicel Chiralpak IA column $(5 \mu \mathrm{m}$ particle size, $150 \mathrm{~mm}$ length, $2.1 \mathrm{~mm}$ internal 
diameter). Detection wavelengths were set at 268, 234 and $296 \mathrm{~nm}$. Analyses under reversed phase and normal phase conditions were performed at $25^{\circ} \mathrm{C}$ and $35^{\circ} \mathrm{C}$, respectively. Optical rotations were obtained on a Jasco P-2000 polarimeter and are reported in $\operatorname{deg} \mathrm{mL} \mathrm{g}^{-1} \mathrm{dm}^{-1}$; concentrations are reported in grams per $100 \mathrm{~mL}$.

\subsection{General procedure for the asymmetric a-hydroxylation of quinolones}

The asymmetric $\alpha$-hydroxylation of quinolones $\mathbf{9 a , b , \mathbf { d }}$ was adopted from Lucas-Lopez et al. ${ }^{20}$

An oven-dried bulb of $50 \mathrm{~mL}$, evacuated and back-filled with argon $(5 \times)$, was loaded with $5 \mathrm{~mL}$ of dry tetrahydrofuran and quinolone (1.00 mmol, 1 equiv). Then, the solution was cooled to $-78{ }^{\circ} \mathrm{C}$ and $1.20 \mathrm{~mL}$ of lithiumbis(trimethylsilyl)amide (1 M solution in tetrahydrofuran, $1.20 \mathrm{mmol}, 1.2$ equiv) was added. The reaction was stirred for 30 minutes at $-78{ }^{\circ} \mathrm{C}$ and a solution of Davis' oxaziridine 14 or $15(0.716 \mathrm{~g}, 2.40 \mathrm{mmol}, 2.4$ equiv) in dry tetrahydrofuran $(10 \mathrm{~mL})$ was added via syringe. Subsequently, the mixture was stirred at $-15{ }^{\circ} \mathrm{C}$ for 16 hours before being quenched by the addition of $35 \mathrm{~mL}$ of saturated aqueous $\mathrm{NH}_{4} \mathrm{Cl}$. Saturated aqueous $\mathrm{Na}_{2} \mathrm{~S}_{2} \mathrm{O}_{3}(100 \mathrm{~mL})$ was then added and the reaction mixture was extracted with diethyl ether $(3 \times 150 \mathrm{~mL})$. The combined organic extracts were concentrated in vacuo. The residue was dissolved in $40 \mathrm{~mL}$ of dichloromethane and subsequently washed with $0.3 \mathrm{M}$ aqueous $\mathrm{HCl}$ $(3 \times 60 \mathrm{~mL})$. The combined aqueous layers were washed with $60 \mathrm{~mL}$ of diethyl ether, basified with $3 \mathrm{M}$ aqueous $\mathrm{NaOH}$ until $\mathrm{pH} 10$ was reached, and extracted with ethyl acetate $(2 \times 250 \mathrm{~mL})$. The combined organic extracts were dried over magnesium sulfate and evaporated in vacuo.

\subsection{1. (S)-3a-hydroxy-6-methyl-1-phenyl-1,2,3,3a-tetrahydro-4H-pyrrolo[2,3-b]quinolin-4-one} $((S)-1)^{20}$

$(S)$-blebbistatin $(S)$-1 was synthesized from quinolone 9a (0.276 g, $1.00 \mathrm{mmol}, 1$ equiv) using Davis' oxaziridine 14 (0.716 g, $2.40 \mathrm{mmol}, 2.4$ equiv). Evaporation in vacuo gave (S)-1 (0.250 g, 
$85 \%$ ) as bright yellow powder. The enantiomeric excess was $75 \%$ as determined by chiral HPLC analysis. This powder was redissolved in $10 \mathrm{~mL}$ of boiling acetonitrile and left untouched overnight at room temperature, which afforded $(S)$-blebbistatin $(S)-\mathbf{1}(0.108 \mathrm{~g}, 37 \%)$ as bright yellow crystals with an enantiomeric excess of $>99 \%$. Chiral HPLC: $t_{\mathrm{R}}((S)-\mathbf{1})=7.32 \mathrm{~min}$, $t_{\mathrm{R}}((R)-1)=9.77 \mathrm{~min}$ (Daicel Chiralpak IA column, acetonitrile/water (50:50), $1.0 \mathrm{~mL} \mathrm{~min}^{-1}$, $\left.25^{\circ} \mathrm{C}\right) .{ }^{1} \mathrm{H}$ NMR $\left(400 \mathrm{MHz}\right.$, DMSO-d $\left.\mathrm{d}_{6}\right): \delta=2.23-2.30$ (m, 2H), 2.31 (br. s, 3H), 3.90-4.02 (m, 1H), 4.02-4.12 (m, 1H), $6.84(\mathrm{~s}, 1 \mathrm{H}), 7.13(\mathrm{~d}, J=8.1 \mathrm{~Hz}, 1 \mathrm{H}), 7.15(\mathrm{t}, J=7.3 \mathrm{~Hz}, 1 \mathrm{H}), 7.38(\mathrm{dd}$, $J=8.1,1.8 \mathrm{~Hz}, 1 \mathrm{H}), 7.40-7.47(\mathrm{~m}, 2 \mathrm{H}), 7.54(\mathrm{~d}, J=1.8 \mathrm{~Hz}, 1 \mathrm{H}), 8.09(\mathrm{~d}, J=7.9 \mathrm{~Hz}, 2 \mathrm{H})$. ${ }^{1}$ H NMR spectrum and chiral HPLC chromatograms are provided in Figures S29 and S48-S49, respectively, in the Supporting Information.

\subsection{2. (R)-3a-hydroxy-6-methyl-1-phenyl-1,2,3,3a-tetrahydro-4H-pyrrolo[2,3-b]quinolin-4-one $((R)-1)$}

$(R)$-blebbistatin $(R)$-1 was synthesized from quinolone 9a $(0.138 \mathrm{~g}, 0.500 \mathrm{mmol}, 1$ equiv) using Davis' oxaziridine 15 (0.358 g, $1.20 \mathrm{mmol}, 2.4$ equiv). Evaporation in vacuo resulted in $(R)-1(0.0918 \mathrm{~g}, 63 \%)$ as a yellow powder. The enantiomeric excess was $75 \%$ as determined by chiral HPLC analysis. The powder was redissolved in $5 \mathrm{~mL}$ of boiling acetonitrile and left untouched overnight at room temperature, which resulted in $(R)$-blebbistatin $(R)-\mathbf{1}(0.0299 \mathrm{~g}$, $20 \%$ ) as bright yellow crystals with an enantiomeric excess of 99\%. Chiral HPLC: $t_{\mathrm{R}}((R)-\mathbf{1})=9.77 \mathrm{~min}, t_{\mathrm{R}}((S)-\mathbf{1})=7.31 \mathrm{~min}$ (Daicel Chiralpak IA column, acetonitrile/water (50:50), $\left.1.0 \mathrm{~mL} \mathrm{~min}^{-1}, 25^{\circ} \mathrm{C}\right) .{ }^{1} \mathrm{H}$ NMR $\left(400 \mathrm{MHz}, \mathrm{DMSO}_{-} \mathrm{d}_{6}\right): \delta=2.23-2.30(\mathrm{~m}, 2 \mathrm{H}), 2.31$ (br. s, 3H), 3.90-4.02 (m, 1H), 4.02-4.12 (m, 1H), $6.84(\mathrm{~s}, 1 \mathrm{H}), 7.13(\mathrm{~d}, J=8.1 \mathrm{~Hz}, 1 \mathrm{H}), 7.15(\mathrm{t}$, $J=7.3 \mathrm{~Hz}, 1 \mathrm{H}), 7.38$ (dd, $J=8.1,1.8 \mathrm{~Hz}, 1 \mathrm{H}), 7.40-7.47$ (m, 2H), $7.54(\mathrm{~d}, J=1.8 \mathrm{~Hz}, 1 \mathrm{H}), 8.09$ 
(d, $J=7.9 \mathrm{~Hz}, 2 \mathrm{H}) . \mathrm{MW}=292.33$. Chiral HPLC chromatogram is provided in Figure S50 in the Supporting Information.

\subsection{3. (S)-1-(3-(allyloxy)phenyl)-3a-hydroxy-6-methyl-1,2,3,3a-tetrahydro-4H-pyrrolo[2,3-}

\section{b]quinolin-4-one ((S)-11)}

(S)-3'-allyloxyblebbistatin (S)-11 was synthesized from quinolone 9b $(11.5 \mathrm{~g}, 34.6 \mathrm{mmol}$, 1 equiv) using Davis' oxaziridine 14 (24.8 g, $83.0 \mathrm{mmol}, 2.4$ equiv). Evaporation in vacuo resulted in $(S)-11(8.19 \mathrm{~g}, 68 \%)$ as an orange powder. The enantiomeric excess was $78 \%$ as determined by chiral HPLC analysis. The powder was redissolved in $80 \mathrm{~mL}$ of boiling acetonitrile and left untouched for 30 minutes at room temperature. After 20 minutes crystals had formed. After an additional 10 minutes, the obtained crystals were filtered off. This resulted in $(S)$-3'-allyloxyblebbistatin $(S)-11(2.29 \mathrm{~g}, 19 \%)$ as bright, gold leaf-like crystals with an enantiomeric excess of $>99 \%$. mp $176{ }^{\circ} \mathrm{C}$. Chiral HPLC: $t_{\mathrm{R}}((S)-11)=11.2 \mathrm{~min}, t_{\mathrm{R}}((R)-$ 11) $=14.2 \mathrm{~min}$ (Daicel Chiralpak IA column, acetonitrile/water (50:50), $\left.1.0 \mathrm{~mL} \mathrm{~min}^{-1}, 25^{\circ} \mathrm{C}\right)$. $[\alpha]^{25}{ }_{\mathrm{D}}=-327 \pm 2\left(c=0.11\right.$ in tetrahydrofuran). ${ }^{1} \mathrm{H}$ NMR (400 MHz, DMSO-d $\left.\mathrm{d}_{6}\right): \delta=2.22-2.29$ (m, 2H), $2.31(\mathrm{~s}, 3 \mathrm{H}), 3.92-4.00(\mathrm{~m}, 1 \mathrm{H}), 4.00-4.09(\mathrm{~m}, 1 \mathrm{H}), 4.62(\mathrm{dt}, J=5.2,1.5 \mathrm{~Hz}, 2 \mathrm{H}), 5.29$ (dq, $J=10.6,1.5 \mathrm{~Hz}, 1 \mathrm{H}), 5.44$ (dq, $J=17.3,1.5 \mathrm{~Hz}, 1 \mathrm{H}), 6.09$ (ddt, $J=17.3,10.6,5.2 \mathrm{~Hz}, 1 \mathrm{H})$, $6.75(\mathrm{dd}, J=8.2,2.0 \mathrm{~Hz}, 1 \mathrm{H}), 6.83(\mathrm{~s}, 1 \mathrm{H}), 7.14(\mathrm{~d}, J=8.1 \mathrm{~Hz}, 1 \mathrm{H}), 7.32(\mathrm{t}, J=8.2 \mathrm{~Hz}, 1 \mathrm{H})$, $7.39(\mathrm{dd}, J=8.1,1.8 \mathrm{~Hz}, 1 \mathrm{H}), 7.50(\mathrm{dd}, J=8.2,2.0 \mathrm{~Hz}, 1 \mathrm{H}), 7.54(\mathrm{~d}, J=1.8 \mathrm{~Hz}, 1 \mathrm{H}), 7.99(\mathrm{t}$, $J=2.0 \mathrm{~Hz}, 1 \mathrm{H}) .{ }^{13} \mathrm{C}$ NMR $\left(100.6 \mathrm{MHz}, \mathrm{DMSO}-\mathrm{d}_{6}\right): \delta=20.7,28.7,48.0,68.7,73.4,106.9$, $110.3,112.2,118.0,121.5,126.4,126.8,129.9,132.9,134.2,137.0,142.2,149.4,158.8,165.8$ 195.0. MS (ESI): $m / z(\%)=348.6\left([\mathrm{M}+\mathrm{H}]^{+}, 100\right)$. HRMS (ESI): calculated for $\mathrm{C}_{21} \mathrm{H}_{21} \mathrm{~N}_{2} \mathrm{O}_{3}$ $\left([\mathrm{M}+\mathrm{H}]^{+}\right)$349.1547; found 349.1544. $\mathrm{MW}=348.40 .{ }^{1} \mathrm{H}$ NMR spectrum, ${ }^{13} \mathrm{C}$ NMR spectrum and 
chiral HPLC chromatograms are provided in Figures S30-S31 and Figures S51-S52 in the Supporting Information.

\subsection{4. (R)-1-(3-(allyloxy)phenyl)-3a-hydroxy-6-methyl-1,2,3,3a-tetrahydro-4H-pyrrolo[2,3-}

\section{b]quinolin-4-one ((R)-11)}

$(R)$-3'-allyloxyblebbistatin $(R)$-11 was synthesized from quinolone 9b $(2.66 \mathrm{~g}, 8.00 \mathrm{mmol}$, 1 equiv) using Davis' oxaziridine 15 (5.73 g, $19.2 \mathrm{mmol}, 2.4$ equiv). Evaporation in vacuo resulted in $(R)-11(2.15 \mathrm{~g}, 77 \%)$ as an orange powder. The enantiomeric excess was $79 \%$ as determined by chiral HPLC analysis. The powder was redissolved in $20 \mathrm{~mL}$ of boiling acetonitrile and left untouched for 30 minutes at room temperature. After 20 minutes crystals had formed, which were filtered off after an additional 10 minutes. This resulted in $(R)-3^{\prime}-$ allyloxyblebbistatin $(R)-11(1.00 \mathrm{~g}, 36 \%)$ as bright, gold leaf-like crystals with an enantiomeric excess of $>99 \%$. $\mathrm{mp} 170{ }^{\circ} \mathrm{C}$. Chiral HPLC: $t_{\mathrm{R}}((R)-\mathbf{1 1})=14.2 \mathrm{~min}, t_{\mathrm{R}}((S)-\mathbf{1 1})=11.2 \mathrm{~min}$ (Daicel Chiralpak IA column, acetonitrile/water $\left.(50: 50), 1.0 \mathrm{~mL} \mathrm{~min}^{-1}, 25^{\circ} \mathrm{C}\right) .[\alpha]^{25}{ }_{\mathrm{D}}=+313 \pm 3$ $\left(c=0.12\right.$ in tetrahydrofuran). ${ }^{1} \mathrm{H}$ NMR $\left(400 \mathrm{MHz}, \mathrm{DMSO}_{\mathrm{d}}\right): \delta=2.22-2.29(\mathrm{~m}, 2 \mathrm{H}), 2.31(\mathrm{~s}$, $3 \mathrm{H}), 3.92-4.00(\mathrm{~m}, 1 \mathrm{H}), 4.00-4.09(\mathrm{~m}, 1 \mathrm{H}), 4.62(\mathrm{dt}, J=5.2,1.5 \mathrm{~Hz}, 2 \mathrm{H}), 5.29(\mathrm{dq}, J=10.6$, $1.5 \mathrm{~Hz}, 1 \mathrm{H}), 5.44$ (dq, $J=17.3,1.5 \mathrm{~Hz}, 1 \mathrm{H}), 6.09$ (ddt, $J=17.3,10.6,5.2 \mathrm{~Hz}, 1 \mathrm{H}), 6.75$ (dd, $J=8.2,2.0 \mathrm{~Hz}, 1 \mathrm{H}), 6.83(\mathrm{~s}, 1 \mathrm{H}), 7.14(\mathrm{~d}, J=8.1 \mathrm{~Hz}, 1 \mathrm{H}), 7.32(\mathrm{t}, J=8.2 \mathrm{~Hz}, 1 \mathrm{H}), 7.39(\mathrm{dd}$, $J=8.1,1.8 \mathrm{~Hz}, 1 \mathrm{H}), 7.50(\mathrm{dd}, J=8.2,2.0 \mathrm{~Hz}, 1 \mathrm{H}), 7.54(\mathrm{~d}, J=1.8 \mathrm{~Hz}, 1 \mathrm{H}), 7.99$ (t, $J=2.0 \mathrm{~Hz}$ 1H). ${ }^{13} \mathrm{C}$ NMR (100.6 MHz, DMSO-d $\left.\mathrm{d}_{6}\right): \delta=20.7,28.7,48.0,68.7,73.4,106.9,110.3,112.2$, 118.0, 121.5, 126.4, 126.8, 129.9, 132.9, 134.2, 137.0, 142.2, 149.4, 158.8, 165.8, 195.0. MS (ESI): $m / z(\%)=348.6\left([\mathrm{M}+\mathrm{H}]^{+}, 100\right)$. HRMS (ESI): calculated for $\mathrm{C}_{21} \mathrm{H}_{21} \mathrm{~N}_{2} \mathrm{O}_{3}\left([\mathrm{M}+\mathrm{H}]^{+}\right)$ 349.1547; found 349.1551. MW $=348.40$. Chiral HPLC chromatogram is provided in Figure S53 in the Supporting Information. 


\subsection{5. (S)-1-(3-(diallylamino)phenyl)-3a-hydroxy-6-methyl-1,2,3,3a-tetrahydro-4H-pyrrolo[2,3-}

\section{b]quinolin-4 one ((S)-12)}

$(S)-3$ '-diallylaminoblebbistatin $(S)$-12 was synthesized from the crude quinolone 9c $(3.96 \mathrm{~g}$, 10.7 mmol, 1 equiv) using Davis' oxaziridine 14 (7.64 g, 25.6 mmol, 2.4 equiv). Evaporation in vacuo resulted in $(S)-\mathbf{1 2}(3.02 \mathrm{~g}, 73 \%)$ as an orange powder. The enantiomeric excess was $76 \%$ as determined by chiral HPLC analysis. The powder was redissolved in $60 \mathrm{~mL}$ of boiling absolute ethanol and left untouched for 1 hour at room temperature. After 40 minutes fibers had formed, which were filtered off after an additional 20 minutes. This resulted in $(S)-3$ 'diallylaminoblebbistatin $(S)-\mathbf{1 2}(1.03 \mathrm{~g}, 25 \%)$ as bright orange cotton-like fibers with an enantiomeric excess of $>99 \%$. mp $167^{\circ} \mathrm{C} . \quad$ Chiral HPLC: $t_{\mathrm{R}}((S)-12)=27.1 \mathrm{~min}$, $t_{\mathrm{R}}((R)-12)=31.1 \mathrm{~min}$ (Daicel Chiralpak IA column, acetonitrile/water (45:55), $1.0 \mathrm{~mL} \mathrm{~min}^{-1}$, $\left.25{ }^{\circ} \mathrm{C}\right) . \quad[\alpha]^{25} \mathrm{D}=-248 \pm 2 \quad\left(c=0.11\right.$ in tetrahydrofuran). ${ }^{1} \mathrm{H}$ NMR (400 MHz, DMSO-d 6 ): $\delta=2.19-2.27(\mathrm{~m}, 2 \mathrm{H}), 2.30(\mathrm{~s}, 3 \mathrm{H}), 3.87-3.95(\mathrm{~m}, 1 \mathrm{H}), 3.94-4.07(\mathrm{~m}, 5 \mathrm{H}), 3.12-5.24(\mathrm{~m}, 4 \mathrm{H})$, $5.92(\mathrm{ddt}, J=17.1,10.2,5.1 \mathrm{~Hz}, 2 \mathrm{H}), 6.47(\mathrm{dd}, J=8.1,2.0 \mathrm{~Hz}, 1 \mathrm{H}), 6.79(\mathrm{~s}, 1 \mathrm{H}), 6.98$ (dd, $J=8.1,2.0 \mathrm{~Hz}, 1 \mathrm{H}), 7.07(\mathrm{~d}, J=8.1 \mathrm{~Hz}, 1 \mathrm{H}), 7.15(\mathrm{t}, J=8.1 \mathrm{~Hz}, 1 \mathrm{H}), 7.38(\mathrm{dd}, J=8.1,1.8 \mathrm{~Hz}$ 1H), $7.52(\mathrm{~d}, J=1.8 \mathrm{~Hz}, 1 \mathrm{H}), 7.94(\mathrm{t}, J=2.0 \mathrm{~Hz}, 1 \mathrm{H}) .{ }^{13} \mathrm{C}$ NMR (100.6 MHz, DMSO-d 6 ): $\delta=20.7,28.8,47.9,53.0,73.5,104.8,107.4,108.3,116.4,121.4,126.2,126.8,129.4,132.5$ $134.8,137.0,141.9,148.9,149.8,165.7,195.1$. MS $(\mathrm{ESI}): m / z(\%)=387.5\left([\mathrm{M}+\mathrm{H}]^{+}, 100\right)$. HRMS (ESI): calculated for $\mathrm{C}_{24} \mathrm{H}_{26} \mathrm{~N}_{3} \mathrm{O}_{2}\left([\mathrm{M}+\mathrm{H}]^{+}\right)$388.2020; found 388.2035. MW = 387.47. ${ }^{1} \mathrm{H}$ NMR spectrum, ${ }^{13} \mathrm{C}$ NMR spectrum and chiral HPLC chromatograms are provided in Figures S34-S35 and Figures S57-S58 in the Supporting Information. 


\section{pyrrolo[2,3-b]quinolin-4 one ((R)-12)}

$(R)$-3'-diallylaminoblebbistatin $(R)$-12 was synthesized from the crude quinolone $\mathbf{9 c}(0.967 \mathrm{~g}$, 2.60 mmol, 1 equiv) using Davis' oxaziridine 15 (1.86 g, 6.24 mmol, 2.4 equiv). Evaporation in vacuo resulted in $(R)-3^{\prime}$-diallylaminoblebbistatin $(R)-12(0.686 \mathrm{~g}, 68 \%)$ as an orange powder. The enantiomeric excess was $74 \%$ as determined by chiral HPLC analysis. The powder was redissolved in $15 \mathrm{~mL}$ of boiling absolute ethanol and left untouched for 50 minutes at room temperature. After 30 minutes fibers had formed, which were filtered off after an additional 20 minutes. This resulted in $(R)$-3'-diallylaminoblebbistatin $(R)-\mathbf{1 2}(0.160 \mathrm{~g}, 16 \%)$ as bright orange cotton-like fibers with an enantiomeric excess of $98 \%$. mp $167^{\circ} \mathrm{C}$. Chiral HPLC: $t_{\mathrm{R}}((R)-\mathbf{1 2})=31.1 \mathrm{~min}, t_{\mathrm{R}}((S)-\mathbf{1 2})=27.7 \mathrm{~min}$ (Daicel Chiralpak IA column, acetonitrile/water (45:55), $\left.\quad 1.0 \mathrm{~mL} \mathrm{~min}^{-1}, \quad 25^{\circ} \mathrm{C}\right) . \quad[\alpha]^{25}{ }_{\mathrm{D}}=+327 \pm 3 \quad\left(c=0.18\right.$ in tetrahydrofuran). ${ }^{1} \mathrm{H}$ NMR $\left(400 \mathrm{MHz}\right.$, DMSO-d $\left.\mathrm{d}_{6}\right): \delta=2.19-2.27(\mathrm{~m}, 2 \mathrm{H}), 2.30(\mathrm{~s}, 3 \mathrm{H}), 3.87-3.95(\mathrm{~m}, 1 \mathrm{H}), 3.94-4.07(\mathrm{~m}$, 5H), 3.12-5.24 (m, 4H), 5.92 (ddt, $J=17.1,10.2,5.1 \mathrm{~Hz}, 2 \mathrm{H}), 6.47$ (dd, $J=8.1,2.0 \mathrm{~Hz}, 1 \mathrm{H}$ ), $6.79(\mathrm{~s}, 1 \mathrm{H}), 6.98(\mathrm{dd}, J=8.1,2.0 \mathrm{~Hz}, 1 \mathrm{H}), 7.07(\mathrm{~d}, J=8.1 \mathrm{~Hz}, 1 \mathrm{H}), 7.15(\mathrm{t}, J=8.1 \mathrm{~Hz}, 1 \mathrm{H})$, $7.38(\mathrm{dd}, J=8.1,1.8 \mathrm{~Hz}, 1 \mathrm{H}), 7.52(\mathrm{~d}, J=1.8 \mathrm{~Hz}, 1 \mathrm{H}), 7.94(\mathrm{t}, J=2.0 \mathrm{~Hz}, 1 \mathrm{H}) .{ }^{13} \mathrm{C} \mathrm{NMR}$ (100.6 MHz, DMSO-d 6 ): $\delta=20.7,28.8,47.9,53.0,73.5,104.8,107.4,108.3,116.4,121.4$, 126.2, 126.8, 129.4, 132.5, 134.8, 137.0, 141.9, 148.9, 149.8, 165.7, 195.1. MS (ESI): $m / z(\%)=$ $387.5\left([\mathrm{M}+\mathrm{H}]^{+}, 100\right)$. HRMS (ESI): calculated for $\mathrm{C}_{24} \mathrm{H}_{26} \mathrm{~N}_{3} \mathrm{O}_{2}\left([\mathrm{M}+\mathrm{H}]^{+}\right)$388.2020; found 388.2023. $\mathrm{MW}=387.47$. Chiral HPLC chromatogram is provided in Figure $\mathrm{S} 60$ in the Supporting Information. 


\subsection{7. (S)-3-(3a-hydroxy-6-methyl-4-oxo-2,3,3a,4-tetrahydro-1H-pyrrolo[2,3-b]quinolin-1-}

yl)benzonitrile ((S)-13)

$(S)-3$ '-cyanoblebbistatin $(S)$-13 was synthesized from quinolone 9d $(1.51 \mathrm{~g}, 5.00 \mathrm{mmol}$, 1 equiv) using Davis' oxaziridine 14 (3.58 g, $12.0 \mathrm{mmol}, 2.4$ equiv). Evaporation in vacuo resulted in $(S)-\mathbf{1 3}(1.54 \mathrm{~g}, 97 \%)$ as a yellow powder. The enantiomeric excess was $83 \%$ as determined by chiral HPLC analysis. $\mathrm{mp} 235^{\circ} \mathrm{C}$. Chiral HPLC: $t_{\mathrm{R}}((S)-13)=7.68 \mathrm{~min}$, $t_{\mathrm{R}}((R)-\mathbf{1 3})=10.1 \mathrm{~min}\left(\right.$ Daicel Chiralpak IA column, acetonitrile/water (50:50), $1.0 \mathrm{~mL} \mathrm{~min}^{-1}$, $\left.25^{\circ} \mathrm{C}\right) . \quad[\alpha]_{\mathrm{D}}^{25}=-248 \pm 2\left(c=0.11\right.$ in tetrahydrofuran). ${ }^{1} \mathrm{H}$ NMR $\left(400 \mathrm{MHz}\right.$, DMSO- $\left.\mathrm{d}_{6}\right)$ : $\delta=2.25-2.36(\mathrm{~m}, 5 \mathrm{H}), 3.97-4.12(\mathrm{~m}, 2 \mathrm{H}), 6.92(\mathrm{~s}, 1 \mathrm{H}), 7.19(\mathrm{~d}, J=8.2 \mathrm{~Hz}, 1 \mathrm{H}), 7.42(\mathrm{dd}$, $J=8.2,2.0 \mathrm{~Hz}, 1 \mathrm{H}), 7.57(\mathrm{~d}, J=2.0 \mathrm{~Hz}, 1 \mathrm{H}), 7.59(\mathrm{dt}, J=8.0,1.3 \mathrm{~Hz}, 1 \mathrm{H}), 7.65(\mathrm{t}, J=8.0 \mathrm{~Hz}$ 1H), 8.45 (ddd, $J=8.0,2.2,1.1 \mathrm{~Hz}, 1 \mathrm{H}), 8.61(\mathrm{t}, J=1.7 \mathrm{~Hz}, 1 \mathrm{H}) .{ }^{13} \mathrm{C}$ NMR $(100.6 \mathrm{MHz}$, DMSO-d $\left.{ }_{6}\right): \delta=20.7,28.6,47.8,73.2,112.1,119.3,121.6,122.6,124.2,126.6,126.9,127.1$, 130.6, 133.6, 137.0, 141.7, 148.7, 165.9, 194.7. MS (ESI): $m / z(\%)=317.6\left([\mathrm{M}+\mathrm{H}]^{+}, 100\right)$. HRMS (ESI): calculated for $\mathrm{C}_{19} \mathrm{H}_{16} \mathrm{~N}_{3} \mathrm{O}_{2}\left([\mathrm{M}+\mathrm{H}]^{+}\right)$318.1237; found 318.1247. $\mathrm{MW}=317.35$.

${ }^{1} \mathrm{H}$ NMR spectrum, ${ }^{13} \mathrm{C}$ NMR spectrum and chiral HPLC chromatograms are provided in Figures S32-S33 and Figures S54-S55 in the Supporting Information.

\subsection{8. (R)-3-(3a-hydroxy-6-methyl-4-oxo-2,3,3a,4-tetrahydro-1H-pyrrolo[2,3-b]quinolin-1-} yl)benzonitrile ((R)-13)

(R)-3'-cyanoblebbistatin $(R)-\mathbf{1 3}$ was synthesized from quinolone 9d $(1.51 \mathrm{~g}, 5.00 \mathrm{mmol}$, 1 equiv) using Davis' oxaziridine 15 (3.58 g, $12.0 \mathrm{mmol}, 2.4$ equiv). Evaporation in vacuo resulted in $(R)-\mathbf{1 3}(1.50 \mathrm{~g}, 95 \%)$ as a yellow powder. The enantiomeric excess was $84 \%$ as determined by chiral HPLC analysis. $\mathrm{mp} 232^{\circ} \mathrm{C}$. Chiral HPLC: $t_{\mathrm{R}}((R)-\mathbf{1 3})=9.88 \mathrm{~min}$, $t_{\mathrm{R}}((S)-13)=7.67 \mathrm{~min}$ (Daicel Chiralpak IA column, acetonitrile/water $(50: 50), 1.0 \mathrm{~mL} \mathrm{~min}^{-1}$, 
$\left.25^{\circ} \mathrm{C}\right) . \quad[\alpha]^{25}=+251 \pm 2 \quad\left(c=0.14\right.$ in tetrahydrofuran). ${ }^{1} \mathrm{H}$ NMR $\left(400 \mathrm{MHz}\right.$, DMSO $\left.-\mathrm{d}_{6}\right)$ : $\delta=2.25-2.36(\mathrm{~m}, 5 \mathrm{H}), 3.97-4.12(\mathrm{~m}, 2 \mathrm{H}), 6.92(\mathrm{~s}, 1 \mathrm{H}), 7.19(\mathrm{~d}, J=8.2 \mathrm{~Hz}, 1 \mathrm{H}), 7.42(\mathrm{dd}$, $J=8.2,2.0 \mathrm{~Hz}, 1 \mathrm{H}), 7.57(\mathrm{~d}, J=2.0 \mathrm{~Hz}, 1 \mathrm{H}), 7.59(\mathrm{dt}, J=8.0,1.3 \mathrm{~Hz}, 1 \mathrm{H}), 7.65(\mathrm{t}, J=8.0 \mathrm{~Hz}$ $1 \mathrm{H}), 8.45(\mathrm{ddd}, J=8.0,2.2,1.1 \mathrm{~Hz}, 1 \mathrm{H}), 8.61(\mathrm{t}, J=1.7 \mathrm{~Hz}, 1 \mathrm{H}) .{ }^{13} \mathrm{C}$ NMR $(100.6 \mathrm{MHz}$, DMSO-d $\left.{ }_{6}\right): \delta=20.7,28.6,47.8,73.2,112.1,119.3,121.6,122.6,124.2,126.6,126.9,127.1$, 130.6, 133.6, 137.0, 141.7, 148.7, 165.9, 194.7. MS (ESI): $m / z(\%)=317.6\left([\mathrm{M}+\mathrm{H}]^{+}, 100\right)$. HRMS (ESI): calculated for $\mathrm{C}_{19} \mathrm{H}_{16} \mathrm{~N}_{3} \mathrm{O}_{2}\left([\mathrm{M}+\mathrm{H}]^{+}\right)$318.1237; found 318.1236. $\mathrm{MW}=317.35$. Chiral HPLC chromatogram is provided in Figure S56 in the Supporting Information.

\subsection{General procedure for the allyl deprotection of allyl phenyl ethers}

The allyl deprotection of allyl phenyl ethers $(S)-\mathbf{1 1}$ and $(R)-\mathbf{1 1}$ was adopted from a publication of Vutukuri et al. ${ }^{33}$

In a flame-dried bulb of $250 \mathrm{~mL}$ containing $200 \mathrm{~mL}$ of dry methanol, allyl phenyl ether (4.21 mmol, 1 equiv) and $0.243 \mathrm{~g}$ of tetrakis(triphenylphosphine)palladium(0) $(0.211 \mathrm{mmol}$, 0.05 equiv) were brought together under a nitrogen atmosphere and stirred for 5 minutes at room temperature. Then, $3.49 \mathrm{~g}$ of $\mathrm{K}_{2} \mathrm{CO}_{3}(25.3 \mathrm{mmol}, 6$ equiv) was added and the reaction mixture was stirred for 1 hour at $50{ }^{\circ} \mathrm{C}$. Afterwards, the mixture was concentrated to a volume of $25 \mathrm{~mL}$, diluted with $400 \mathrm{~mL}$ of ethyl acetate, washed with saturated aqueous $\mathrm{NH}_{4} \mathrm{Cl}(2 \times 75 \mathrm{~mL})$. Next, the organic layer was dried over magnesium sulfate and evaporated in vacuo.

1.3.1. (S)-3a-hydroxy-1-(3-hydroxyphenyl)-6-methyl-1,2,3,3a-tetrahydro-4H-pyrrolo[2,3b]quinolin-4-one ((S)-2)

$(S)-3$ '-hydroxyblebbistatin $(S)$-2 was synthesized from $(S)$-3'-allyloxyblebbistatin (S)-11 $(1.47 \mathrm{~g}, 4.21 \mathrm{mmol}, 1$ equiv). Evaporation in vacuo afforded a bright red powder $(1.53 \mathrm{~g})$ which was dissolved in tetrahydrofuran and coated under reduced pressure onto $4.60 \mathrm{~g}$ of silica. 
Subsequently, purification was performed via automated flash chromatography with hexane/ethyl acetate as eluent on a Reveleris ${ }^{\circledR} 80 \mathrm{~g}$ silica cartridge ( $2 \%$ sample loading; flow rate: $60 \mathrm{~mL} \mathrm{~min}^{-1}$; eluent: $2 \mathrm{CV}$ of $15 \%$ ethyl acetate, followed by a gradient from $15 \%$ to $100 \%$ ethyl acetate over $15 \mathrm{CV}$ and finally $2 \mathrm{CV}$ of $100 \%$ ethyl acetate; detection wavelengths: $220 \mathrm{~nm}$ and $264 \mathrm{~nm})$. This resulted in $(S)-3$ '-hydroxyblebbistatin $(S)-2(1.03 \mathrm{~g}, 79 \%)$ as a bright orange powder. The enantiomeric excess was $99 \%$ as determined by chiral HPLC analysis. mp $179^{\circ} \mathrm{C}$. $R_{f}=0.40$ (hexane/ethyl acetate, 2:3). Chiral HPLC: $t_{\mathrm{R}}((S)-2)=3.87 \mathrm{~min}, t_{\mathrm{R}}((R)-\mathbf{2})=5.18 \mathrm{~min}$ (Daicel Chiralpak IA column, acetonitrile/water (50:50), $\left.1.0 \mathrm{~mL} \mathrm{~min}^{-1}, 25^{\circ} \mathrm{C}\right) \cdot[\alpha]^{25}=-332 \pm 3$ ( $c=0.11$ in tetrahydrofuran). ${ }^{1} \mathrm{H}$ NMR (400 MHz, DMSO-d $\left.{ }_{6}\right): \delta=2.20-2.27(\mathrm{~m}, 2 \mathrm{H}), 2.31(\mathrm{~s}$, 3H), 3.87-3.95 (m, 1H), 3.96-4.06 (m, 1H), $6.56(\mathrm{dd}, J=8.1,2.1 \mathrm{~Hz}, 1 \mathrm{H}), 6.81(\mathrm{~s}, 1 \mathrm{H}), 7.12(\mathrm{~d}$, $J=8.1 \mathrm{~Hz}, 1 \mathrm{H}), 7.19(\mathrm{t}, J=8.1 \mathrm{~Hz}, 1 \mathrm{H}), 7.35-7.41(\mathrm{~m}, 2 \mathrm{H}), 7.53(\mathrm{~d}, J=1.6 \mathrm{~Hz}, 1 \mathrm{H}), 7.71(\mathrm{t}$, $J=2.1 \mathrm{~Hz}, 1 \mathrm{H}), 9.50(\mathrm{~s}, 1 \mathrm{H}) .{ }^{13} \mathrm{C}$ NMR $\left(100.6 \mathrm{MHz}, \mathrm{DMSO}_{\mathrm{d}}\right): \delta=20.7,28.7,48.0,73.4$, 107.6, 110.8, 111.2, 121.4, 126.3, 126.8, 129.8, 132.7, 136.9, 142.1, 149.7, 158.0, 165.7, 195.1. MS (ESI): $m / z(\%)=308.7\left([\mathrm{M}+\mathrm{H}]^{+}, 100\right)$. HRMS (ESI): calculated for $\mathrm{C}_{18} \mathrm{H}_{17} \mathrm{~N}_{2} \mathrm{O}_{3}\left([\mathrm{M}+\mathrm{H}]^{+}\right)$ 309.1234; found 309.1233. MW $=308.33$. ${ }^{1} \mathrm{H}$ NMR spectrum, ${ }^{13} \mathrm{C}$ NMR spectrum and chiral HPLC chromatograms are provided in Figures S36-S37 and Figures S60-S61 in the Supporting Information. X-ray data are provided in Figures S1-S2 in the Supporting Information.

\subsection{2. (R)-3a-hydroxy-1-(3-hydroxyphenyl)-6-methyl-1,2,3,3a-tetrahydro-4H-pyrrolo[2,3-}

\section{b]quinolin-4-one ((R)-2)}

$(R)$-3'-hydroxyblebbistatin $(R)$-2 was synthesized from $(R)$-3'-allyloxyblebbistatin $(R)$-11 $(0.182 \mathrm{~g}, 0.521 \mathrm{mmol}, 1$ equiv). Evaporation in vacuo afforded an orange oil $(0.200 \mathrm{~g})$ which was dissolved in tetrahydrofuran and coated under reduced pressure onto $0.600 \mathrm{~g}$ of silica. Subsequently, purification was performed via automated flash chromatography with 
hexane/ethyl acetate as eluent on a Reveleris ${ }^{\circledR} 12 \mathrm{~g}$ silica cartridge (2\% sample loading; flow rate: $36 \mathrm{~mL} \mathrm{~min}^{-1}$; eluent: $2 \mathrm{CV}$ of $15 \%$ ethyl acetate, followed by a gradient from $15 \%$ to $100 \%$ ethyl acetate over $15 \mathrm{CV}$ and finally $2 \mathrm{CV}$ of $100 \%$ ethyl acetate; detection wavelengths: $220 \mathrm{~nm}$ and $264 \mathrm{~nm})$. This resulted in $(R)-3^{\prime}$ '-hydroxyblebbistatin $(R)-2(0.120 \mathrm{~g}, 75 \%)$ as a bright orange powder. The enantiomeric excess was $98 \%$ as determined by chiral HPLC analysis. mp $202{ }^{\circ} \mathrm{C}$. $R_{f}=0.40$ (hexane/ethyl acetate, 2:3). Chiral HPLC: $t_{\mathrm{R}}((R)-\mathbf{2})=5.11 \mathrm{~min}, t_{\mathrm{R}}((S)-\mathbf{2})=3.91 \mathrm{~min}$ (Daicel Chiralpak IA column, acetonitrile/water $\left.(50: 50), 1.0 \mathrm{~mL} \mathrm{~min}^{-1}, 25{ }^{\circ} \mathrm{C}\right) \cdot[\alpha]^{25} \mathrm{D}=+320 \pm 3$ ( $c=0.12$ in tetrahydrofuran). ${ }^{1} \mathrm{H}$ NMR $\left(400 \mathrm{MHz}, \mathrm{DMSO}-\mathrm{d}_{6}\right): \delta=2.20-2.27(\mathrm{~m}, 2 \mathrm{H}), 2.31(\mathrm{~s}$, 3H), 3.87-3.95 (m, 1H), 3.96-4.06 (m, 1H), $6.56(\mathrm{dd}, J=8.1,2.1 \mathrm{~Hz}, 1 \mathrm{H}), 6.81(\mathrm{~s}, 1 \mathrm{H}), 7.12(\mathrm{~d}$, $J=8.1 \mathrm{~Hz}, 1 \mathrm{H}), 7.19(\mathrm{t}, J=8.1 \mathrm{~Hz}, 1 \mathrm{H}), 7.35-7.41(\mathrm{~m}, 2 \mathrm{H}), 7.53(\mathrm{~d}, J=1.6 \mathrm{~Hz}, 1 \mathrm{H}), 7.71(\mathrm{t}$, $J=2.1 \mathrm{~Hz}, 1 \mathrm{H}), 9.50(\mathrm{~s}, 1 \mathrm{H}) .{ }^{13} \mathrm{C}$ NMR $\left(100.6 \mathrm{MHz}, \mathrm{DMSO}-\mathrm{d}_{6}\right): \delta=20.7,28.7,48.0,73.4$, 107.6, 110.8, 111.2, 121.4, 126.3, 126.8, 129.8, 132.7, 136.9, 142.1, 149.7, 158.0, 165.7, 195.1. MS (ESI): $m / z(\%)=308.6\left([\mathrm{M}+\mathrm{H}]^{+}, 100\right)$. HRMS (ESI): calculated for $\mathrm{C}_{18} \mathrm{H}_{17} \mathrm{~N}_{2} \mathrm{O}_{3}\left([\mathrm{M}+\mathrm{H}]^{+}\right)$ 309.1234; found 309.1239. MW $=308.33$. Chiral HPLC chromatogram is provided in Figure S62 in the Supporting Information. X-ray data are provided in Figures S3-S4 in the Supporting Information.

\subsection{General procedure for the allyl deprotection of diallyl phenyl amines}

The allyl deprotection of diallyl phenyl amines $(S)-\mathbf{1 2}$ and $(R)-\mathbf{1 2}$ was based on a publication of Belardi and Micalizio. ${ }^{34}$

In a flame-dried bulb of $25 \mathrm{~mL}$ containing $20 \mathrm{~mL}$ of dry dichloromethane, $0.358 \mathrm{~g}$ of diallyl phenyl amine ( $0.924 \mathrm{mmol}, 1$ equiv), $0.865 \mathrm{~g}$ of $N, N^{\prime}$-dimethylbarbituric acid $(5.55 \mathrm{mmol}$, 6 equiv) and $0.106 \mathrm{~g}$ of tetrakis(triphenylphosphine)palladium(0) $(0.0924 \mathrm{mmol}, 0.1$ equiv) were brought together under a nitrogen atmosphere and stirred for 1 hour at reflux temperature. 
Afterwards, the reaction mixture cooled to room temperature, diluted with $150 \mathrm{~mL}$ of ethyl acetate and washed with saturated aqueous $\mathrm{NaHCO}_{3}(2 \times 50 \mathrm{~mL})$. The organic layer was dried over magnesium sulfate and evaporated in vacuo.

\subsection{1. (S)-1-(3-aminophenyl)-3a-hydroxy-6-methyl-1,2,3,3a-tetrahydro-4H-pyrrolo[2,3-}

\section{b]quinolin-4-one ((S)-3)}

$(S)-3$ '-aminoblebbistatin $(S)$-3 was synthesized from $(S)$-3'-diallylaminoblebbistatin $(S)$-12 (0.358 g, $0.924 \mathrm{mmol}, 1$ equiv). Evaporation in vacuo afforded a brown oil (0.496 g) which was taken up in tetrahydrofuran and coated under reduced pressure onto $1.49 \mathrm{~g}$ of silica. Subsequently, purification was performed via automated flash chromatography with hexane/ethyl acetate as eluent on a Reveleris ${ }^{\circledR} 40 \mathrm{~g}$ silica cartridge (1\% sample loading; flow rate: $40 \mathrm{~mL} \mathrm{~min}^{-1}$; eluent: $2 \mathrm{CV}$ of $20 \%$ ethyl acetate, followed by a gradient from $20 \%$ to $100 \%$ ethyl acetate over $20 \mathrm{CV}$ and finally $2 \mathrm{CV}$ of $100 \%$ ethyl acetate; detection wavelengths: $220 \mathrm{~nm}$ and $264 \mathrm{~nm})$. This resulted in $(S)$-3'-aminoblebbistatin $(S)-3(0.215 \mathrm{~g}, 76 \%)$ as a dark yelloworange powder. The enantiomeric excess was $>99 \%$ as determined by chiral HPLC analysis. $\mathrm{mp} 207^{\circ} \mathrm{C} . \quad R_{f}=0.33 \quad$ (hexane/ethyl acetate, 1:4). Chiral HPLC: $t_{\mathrm{R}}((S)-3)=4.41 \mathrm{~min}$, $t_{\mathrm{R}}((R)-\mathbf{3})=6.35 \mathrm{~min}$ (Daicel Chiralpak IA column, acetonitrile/water (50:50), $1.0 \mathrm{~mL} \mathrm{~min}^{-1}$, $\left.25^{\circ} \mathrm{C}\right) . \quad[\alpha]^{25}=-383 \pm 3 \quad\left(c=0.10\right.$ in tetrahydrofuran). ${ }^{1} \mathrm{H}$ NMR $\left(400 \mathrm{MHz}\right.$, DMSO- $\left.\mathrm{d}_{6}\right)$ : $\delta=2.18-2.26(\mathrm{~m}, 2 \mathrm{H}), 2.30(\mathrm{~s}, 3 \mathrm{H}), 3.82-3.91(\mathrm{~m}, 1 \mathrm{H}), 3.93-4.05(\mathrm{~m}, 1 \mathrm{H}), 5.14$ (br. s, 2H), 6.37 (dd, $J=8.0,1.8 \mathrm{~Hz}, 1 \mathrm{H}), 6.78(\mathrm{~s}, 1 \mathrm{H}), 7.04(\mathrm{t}, J=8.0 \mathrm{~Hz}, 1 \mathrm{H}), 7.11(\mathrm{~d}, J=8.1 \mathrm{~Hz}, 1 \mathrm{H}), 7.17$ (dd, $J=8.0,1.8 \mathrm{~Hz}, 1 \mathrm{H}), 7.34(\mathrm{t}, J=1.8 \mathrm{~Hz}, 1 \mathrm{H}), 7.37(\mathrm{dd}, J=8.1,1.9 \mathrm{~Hz}, 1 \mathrm{H}), 7.51(\mathrm{~d}$, $J=1.9 \mathrm{~Hz}, 1 \mathrm{H}) .{ }^{13} \mathrm{C}$ NMR $(100.6 \mathrm{MHz}$, DMSO-d 6 ): $\delta=20.7,28.3,48.0,73.4,106.1,108.2$, $110.3,121.4,126.3,126.7,129.4,132.4,136.9,141.7,149.4,150.0,165.6,195.2$. MS (ESI): $m / z(\%)=307.7\left([\mathrm{M}+\mathrm{H}]^{+}, 100\right)$. HRMS (ESI): calculated for $\mathrm{C}_{18} \mathrm{H}_{18} \mathrm{~N}_{3} \mathrm{O}_{2}\left([\mathrm{M}+\mathrm{H}]^{+}\right)$308.1394; 
found 308.1387. $\mathrm{MW}=307.35 .{ }^{1} \mathrm{H}$ NMR spectrum, ${ }^{13} \mathrm{C}$ NMR spectrum and chiral HPLC chromatograms are provided in Figures S38-S39 and Figures S63-S64 in the Supporting Information.

\subsection{2. (R)-1-(3-aminophenyl)-3a-hydroxy-6-methyl-1,2,3,3a-tetrahydro-4H-pyrrolo[2,3-}

\section{b]quinolin-4-one ((R)-3)}

(R)-3'-aminoblebbistatin $(R)$-3 was synthesized from $(R)$-3'-diallylaminoblebbistatin $(R)$-12 $(0.0530 \mathrm{~g}, 0.137 \mathrm{mmol}, 1$ equiv). Evaporation in vacuo afforded a brown oil $(0.0731 \mathrm{~g})$ which was taken up in tetrahydrofuran and coated under reduced pressure onto $0.219 \mathrm{~g}$ of silica. Subsequently, purification was performed via automated flash chromatography with hexane/ethyl acetate as eluent on a Reveleris ${ }^{\circledR} 12 \mathrm{~g}$ silica cartridge (1\% sample loading; flow rate: $36 \mathrm{~mL} \mathrm{~min}^{-1}$; eluent: $2 \mathrm{CV}$ of $20 \%$ ethyl acetate, followed by a gradient from $20 \%$ to $100 \%$ ethyl acetate over $20 \mathrm{CV}$ and finally $2 \mathrm{CV}$ of $100 \%$ ethyl acetate; detection wavelengths: $220 \mathrm{~nm}$ and $264 \mathrm{~nm})$. This resulted in $(R)-3$ '-aminoblebbistatin $(R)-3(0.0301 \mathrm{~g}, 72 \%)$ as a dark yelloworange powder. The enantiomeric excess was $95 \%$ as determined by chiral HPLC analysis. mp $174{ }^{\circ} \mathrm{C} . R_{f}=0.33$ (hexane/ethyl acetate, $\left.1: 4\right)$. Chiral HPLC: $t_{\mathrm{R}}((R)-3)=6.35 \mathrm{~min}, t_{\mathrm{R}}((S)-$ 3) $=4.44 \mathrm{~min}$ (Daicel Chiralpak IA column, acetonitrile/water (50:50), $\left.1.0 \mathrm{~mL} \mathrm{~min}^{-1}, 25^{\circ} \mathrm{C}\right)$. $[\alpha]^{25}=+358 \pm 4\left(c=0.11\right.$ in tetrahydrofuran). ${ }^{1} \mathrm{H}$ NMR (400 MHz, DMSO-d $\left.{ }_{6}\right): \delta=2.18-2.26$ (m, 2H), $2.30(\mathrm{~s}, 3 \mathrm{H}), 3.82-3.91(\mathrm{~m}, 1 \mathrm{H}), 3.93-4.05$ (m, 1H), 5.14 (br. s, 2H), 6.37 (dd, $J=8.0$, $1.8 \mathrm{~Hz}, 1 \mathrm{H}), 6.78(\mathrm{~s}, 1 \mathrm{H}), 7.04$ (t, $J=8.0 \mathrm{~Hz}, 1 \mathrm{H}), 7.11(\mathrm{~d}, J=8.1 \mathrm{~Hz}, 1 \mathrm{H}), 7.17$ (dd, $J=8.0$, $1.8 \mathrm{~Hz}, 1 \mathrm{H}), 7.34(\mathrm{t}, J=1.8 \mathrm{~Hz}, 1 \mathrm{H}), 7.37(\mathrm{dd}, J=8.1,1.9 \mathrm{~Hz}, 1 \mathrm{H}), 7.51(\mathrm{~d}, J=1.9 \mathrm{~Hz}, 1 \mathrm{H})$. ${ }^{13} \mathrm{C}$ NMR (100.6 MHz, DMSO-d $\left.\mathrm{d}_{6}\right): \delta=20.7,28.3,48.0,73.4,106.1,108.2,110.3,121.4,126.3$, $126.7,129.4,132.4,136.9,141.7,149.4,150.0,165.6,195.2$. MS $(\mathrm{ESI}): \mathrm{m} / z(\%)=307.7$ ([M+H $\left.]^{+}, 100\right)$. HRMS (ESI): calculated for $\mathrm{C}_{18} \mathrm{H}_{18} \mathrm{~N}_{3} \mathrm{O}_{2}\left([\mathrm{M}+\mathrm{H}]^{+}\right)$308.1394; found 308.1403. 
MW $=307.35$. Chiral HPLC chromatogram is provided in Figure S65 in the Supporting Information.

\subsection{General procedure for the selective hydrolysis of nitriles to amides}

The selective hydrolysis of nitriles $(S)$-13 and $(R)-13$ to amides $(S)$-16 and $(R)-16$ was performed via an adopted procedure from Fowler et al. ${ }^{35}$

In a flame-dried bulb of $250 \mathrm{~mL}$ containing $150 \mathrm{~mL}$ of dry dichloromethane, nitrile (3.18 mmol, 1 equiv) and $1.31 \mathrm{~mL}$ of $N, N$-diethylhydroxylamine $(12.7 \mathrm{mmol}, 4$ equiv) were brought together under a nitrogen atmosphere and the reaction mixture was stirred at reflux temperature for 24 hours. Next, a second portion of $N, N$-diethylhydroxylamine $(1.31 \mathrm{~mL}$, $12.7 \mathrm{mmol}, 4$ equiv) was added and the reaction mixture was refluxed for another 24 hours. During the reaction, the product had precipitated. After cooling to room temperature, the solids were filtered off on a sintered glass Büchner funnel and rinsed with ice-cold dichloromethane until the filtrate turned colorless. The residue was dried under reduced pressure.

\subsection{1. (S)-3-(3a-hydroxy-6-methyl-4-oxo-2,3,3a,4-tetrahydro-1H-pyrrolo[2,3-b]quinolin-1-} yl)benzamide ((S)-16)

$(S)-3$ '-carbamoylblebbistatin $(S)$-16 was synthesized from $(S)$-3'-cyanoblebbistatin $(S)$-13

(1.01 g, $3.18 \mathrm{mmol}, 1$ equiv). Drying of the residue under reduced pressure afforded $(S)-16$ $(0.969 \mathrm{~g}, 91 \%)$ as an ochreous powder. The enantiomeric excess was $86 \%$ as determined by chiral HPLC analysis. Portions of $190 \mathrm{mg}$ of the powder were redissolved in $80 \mathrm{~mL}$ of boiling absolute ethanol. The cooling solution was left untouched for 24 hours at room temperature, during which time yellow fibers had formed. In one case, evaporation in vacuo of the mother liquor resulted in $(S)$-3'-carbamoylblebbistatin $(S)$-16 (0.152 g, 73\%) as a yellow powder with an enantiomeric excess of $98 \%$. In one other case, the crop afforded $(S)$-3'-carbamoylblebbistatin 
$(S)-16(0.0422 \mathrm{~g}, 20 \%)$ as bright yellow fibers with an enantiomeric excess of $98 \%$. The three other recrystallizations resulted in scalemic mixtures in both the crops and the mother liquors. In those cases the crop and the mother liquor were recombined and the recrystallization protocol was repeated. $\mathrm{mp} 267^{\circ} \mathrm{C}$. Chiral HPLC: $t_{\mathrm{R}}((S)-\mathbf{1 6})=20.9 \mathrm{~min}, t_{\mathrm{R}}((R)-\mathbf{1 6})=17.6 \mathrm{~min}$ (Daicel Chiralpak IA column, hexane/dichloromethane/absolute ethanol (10:90:3), $\left.0.5 \mathrm{~mL} \mathrm{~min}^{-1}, 35^{\circ} \mathrm{C}\right)$. $[\alpha]^{25}=-288 \pm 5(c=0.07$ in tetrahydrofuran $) .{ }^{1} \mathrm{H}$ NMR $\left(400 \mathrm{MHz}\right.$, DMSO-d $\left.{ }_{6}\right): \delta=2.25-2.36$ (m, 5H), 3.97-4.06 (m, 1H), 4.05-4.16 (m, 1H), $6.87(\mathrm{~s}, 1 \mathrm{H}), 7.13$ (d, J=8.1 Hz, 1H), 7.39 (dd, $J=8.1,1.7 \mathrm{~Hz}, 1 \mathrm{H}), 7.42$ (br. s, 1H), $7.51(\mathrm{t}, J=7.9 \mathrm{~Hz}, 1 \mathrm{H}), 7.55(\mathrm{~d}, J=1.7 \mathrm{~Hz}, 1 \mathrm{H}), 7.64(\mathrm{~d}$, $J=7.9 \mathrm{~Hz}, 1 \mathrm{H}$ ), 8.02 (br. s, $1 \mathrm{H}$ ), 8.24 (br. s, $1 \mathrm{H}), 8.52$ (dd, $J=7.9,1.6 \mathrm{~Hz}, 1 \mathrm{H}) .{ }^{13} \mathrm{C} \mathrm{NMR}$ $\left(100.6 \mathrm{MHz}, \mathrm{DMSO}-\mathrm{d}_{6}\right): \delta=20.7,28.8,48.0,73.3,118.9,121.5,122.9,123.2,126.4,126.8$, $129.0,132.9,135.4,136.9,141.0,149.4,165.8,168.2,195.0 . \mathrm{MS}(\mathrm{ESI}): m / z(\%)=335.6$ $\left([\mathrm{M}+\mathrm{H}]^{+}, 100\right)$. HRMS (ESI): calculated for $\mathrm{C}_{19} \mathrm{H}_{18} \mathrm{~N}_{3} \mathrm{O}_{3}\left([\mathrm{M}+\mathrm{H}]^{+}\right)$336.1343; found 336.1346. $\mathrm{MW}=335.36 .{ }^{1} \mathrm{H}$ NMR spectrum, ${ }^{13} \mathrm{C}$ NMR spectrum and chiral HPLC chromatograms are provided in Figures S40-S41 and Figures S66-S67 in the Supporting Information.

\subsection{2. (R)-3-(3a-hydroxy-6-methyl-4-oxo-2,3,3a,4-tetrahydro-1H-pyrrolo[2,3-b]quinolin-1-}

\section{yl)benzamide ((R)-16)}

$(R)$-3'-carbamoylblebbistatin $(R)$-16 was synthesized from $(R)$-3'-cyanoblebbistatin $(R)$-13 (1.01 g, $3.18 \mathrm{mmol}, 1$ equiv). Drying under reduced pressure afforded $(R)-\mathbf{1 6}(0.955 \mathrm{~g}, 90 \%)$ as an ochreous powder. The enantiomeric excess was $86 \%$ as determined by chiral HPLC analysis. Portions of $190 \mathrm{mg}$ of the powder were redissolved in $80 \mathrm{~mL}$ of boiling absolute ethanol. The solutions were left untouched for 24 hours at room temperature, during which time yellow fibers had formed. In one case, evaporation in vacuo of the mother liquor resulted in $(R)-3^{\prime}-$ carbamoylblebbistatin $(R)-\mathbf{1 6}(0.103 \mathrm{~g}, 49 \%)$ as a yellow powder with an enantiomeric excess of 
$97 \%$. The four other recrystallizations resulted in scalemic mixtures in both the crops and the mother liquors. In those cases the crop and the mother liquor were recombined and the crystallization protocol was repeated. $\mathrm{mp} 267^{\circ} \mathrm{C}$. Chiral HPLC: $t_{\mathrm{R}}((R)-\mathbf{1 6})=17.3 \mathrm{~min}$, $t_{\mathrm{R}}((S)-16)=21.4 \mathrm{~min}$ (Daicel Chiralpak IA column, hexane/dichloromethane/absolute ethanol (10:90:3), $\left.\quad 0.5 \mathrm{~mL} \mathrm{~min}^{-1}, \quad 35^{\circ} \mathrm{C}\right) . \quad[\alpha]^{25}=+269 \pm 8 \quad\left(c=0.07\right.$ in tetrahydrofuran). ${ }^{1} \mathrm{H}$ NMR (400 MHz, DMSO-d $\left.\mathrm{d}_{6}\right): \delta=2.25-2.36(\mathrm{~m}, 5 \mathrm{H}), 3.97-4.06(\mathrm{~m}, 1 \mathrm{H}), 4.05-4.16(\mathrm{~m}, 1 \mathrm{H}), 6.87(\mathrm{~s}$, 1H), 7.13 (d, $J=8.1 \mathrm{~Hz}, 1 \mathrm{H}), 7.39$ (dd, $J=8.1,1.7 \mathrm{~Hz}, 1 \mathrm{H}), 7.42$ (br. s, $1 \mathrm{H}), 7.51$ (t, $J=7.9 \mathrm{~Hz}$, 1H), 7.55 (d, $J=1.7 \mathrm{~Hz}, 1 \mathrm{H}), 7.64$ (d, $J=7.9 \mathrm{~Hz}, 1 \mathrm{H}), 8.02$ (br. s, $1 \mathrm{H}), 8.24$ (br. s, $1 \mathrm{H}), 8.52$ (dd, $J=7.9,1.6 \mathrm{~Hz}, 1 \mathrm{H}) .{ }^{13} \mathrm{C} \mathrm{NMR}\left(100.6 \mathrm{MHz}, \mathrm{DMSO}-\mathrm{d}_{6}\right): \delta=20.7,28.8,48.0,73.3,118.9,121.5$, $122.9,123.2,126.4,126.8,129.0,132.9,135.4,136.9,141.0,149.4,165.8,168.2,195.0 . \mathrm{MS}$ (ESI): $m / z(\%)=335.6\left([\mathrm{M}+\mathrm{H}]^{+}, 100\right)$. HRMS (ESI): calculated for $\mathrm{C}_{19} \mathrm{H}_{18} \mathrm{~N}_{3} \mathrm{O}_{3}\left([\mathrm{M}+\mathrm{H}]^{+}\right)$ 336.1343; found 336.1340. $\mathrm{MW}=335.36$. Chiral HPLC chromatogram is provided in Figure S68 in the Supporting Information.

\subsection{General procedure for the hydrolysis of amides to carboxylic acids}

A bulb of $10 \mathrm{~mL}$ was loaded with $4.6 \mathrm{~mL}$ of demineralized water, $0.74 \mathrm{~mL}$ of concentrated $\mathrm{H}_{2} \mathrm{SO}_{4}$ (13.6 mmol, 30 equiv) and amide $(0.457 \mathrm{mmol}, 1$ equiv), after which the reaction mixture was stirred at $70{ }^{\circ} \mathrm{C}$ for 14 hours. The resulting black slurry was filtered off over celite and the filter cake was rinsed with demineralized water until the filtrate turned colorless. Afterwards, the $\mathrm{pH}$ of the yellow filtrate was adjusted to $4-5$ with $3 \mathrm{M}$ aqueous $\mathrm{NaOH}$ and the water was lyophilized during 21 hours $\left(0.31 \mathrm{mbar}, 21^{\circ} \mathrm{C}\right)$. This resulted in a light yellow powder containing the product together with salts such as $\mathrm{Na}_{2} \mathrm{SO}_{4}$. Isolation of the product from this mixture was conducted by stirring the powder in $90 \mathrm{~mL}$ of absolute ethanol for 30 minutes. Next, the solids were filtered off on a sintered glass Büchner funnel. The filter cake was rinsed with 
absolute ethanol until the filtrate turned colorless, upon which the filtrate was evaporated in vacuo.

To overcome the separation difficulties associated with chiral HPLC analysis of carboxylic acids $(S)$-17 and $(R)-\mathbf{1 7}$, an analytical sample was converted into the corresponding methyl esters by means of diazomethane. A vial, equipped with a stirring bar, was loaded with a pinch of carboxylic acid, $0.3 \mathrm{~mL}$ of methanol and 20 drops of freshly prepared diazomethane. For the preparation of diazomethane, see the Supporting Information. CAUTION! Due to the dangers associated with diazomethane handling, sharp edged glassware was avoided, and diazomethane was added using a Pasteur pipette which was fire polished prior to use. When dealing with diazomethane, the experimenter should first thoroughly study the literature on the properties and safe handling of this hazardous reagent. ${ }^{36,37}$ The reaction mixture was stirred at room temperature for 45 minutes, during which the carboxylic acid functionality was almost completely converted into the corresponding methyl ester without affecting the alcohol moiety $\left({ }^{1} \mathrm{H}\right.$ NMR spectrum and LC-MS chromatogram are provided in Figures S44-S47 in the Supporting Information as proofs of conversion). Excess diazomethane and the solvent were evaporated under a flow of nitrogen gas. The yellow residue was redissolved in $1 \mathrm{~mL}$ of acetonitrile and analyzed as such.

\subsection{1. (S)-3-(3a-hydroxy-6-methyl-4-oxo-2,3,3a,4-tetrahydro-1H-pyrrolo[2,3-b]quinolin-1-} yl)benzoic acid ((S)-17)

(S)-3'-carboxyblebbistatin $(S)$-17 was synthesized from $(S)$-3'-carbamoylblebbistatin $(S)$-16 $(0.153 \mathrm{~g}, 0.457 \mathrm{mmol}, 1$ equiv). Evaporation in vacuo of the filtrate afforded a yellow powder (0.108 g) which was dissolved in $2.5 \mathrm{~mL}$ of absolute ethanol and further purified via preparative TLC with dichloromethane/methanol (9:1) as eluent. This resulted in $(S)$-3'-carboxyblebbistatin 
(S)-17 (0.0332 g, 22\%) as a bright orange powder. The enantiomeric excess of the corresponding (S)-methyl ester (see general procedure above) was $96 \%$ as determined by chiral HPLC analysis. mp $250^{\circ}$ C. $R_{\mathrm{f}}=0.14$ (dichloromethane/methanol, 9:1). Chiral HPLC $(S)$-methyl ester: $t_{\mathrm{R}}((S)$ methyl ester $)=61.6 \mathrm{~min}, t_{\mathrm{R}}((R)$-methyl ester $)=73.6 \mathrm{~min} \quad$ (Daicel Chiralpak IA column,

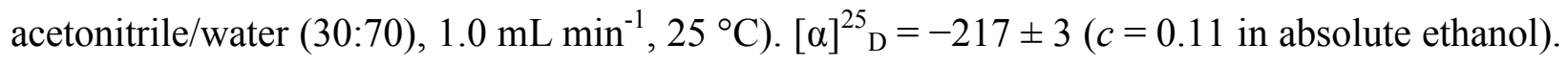

${ }^{1} \mathrm{H}$ NMR (400 MHz, $0.18 \mathrm{M} \mathrm{NaHCO}_{3}$ in $\mathrm{D}_{2} \mathrm{O}$ ): $\delta=2.22(\mathrm{~s}, 3 \mathrm{H}), 2.30-2.38(\mathrm{~m}, 2 \mathrm{H}), 3.91-4.00$ $(\mathrm{m}, 1 \mathrm{H}), 4.05-4.16(\mathrm{~m}, 1 \mathrm{H}), 6.96(\mathrm{~d}, J=8.4 \mathrm{~Hz}, 1 \mathrm{H}), 7.34(\mathrm{~d}, J=8.4 \mathrm{~Hz}, 1 \mathrm{H}), 7.46(\mathrm{t}$, $J=7.9 \mathrm{~Hz}, 1 \mathrm{H}$ ), 7.55 (br. s, 1H), 7.68 (d, $J=7.9 \mathrm{~Hz}, 1 \mathrm{H}), 7.75$ (d, $J=7.9 \mathrm{~Hz}, 1 \mathrm{H}), 7.94$ (br. s, 1H). ${ }^{13} \mathrm{C}$ NMR (100.6 MHz, $0.18 \mathrm{M} \mathrm{NaHCO}_{3}$ in $\left.\mathrm{D}_{2} \mathrm{O}\right): \delta=19.6,28.2,49.4,73.8,120.1,123.1$, $124.8,125.7,126.5,127.2,129.2,133.9,137.5,138.3,138.8,148.8,160.4,166.0,174.8,196.5$. MS (ESI): $m / z(\%)=336.6\left([\mathrm{M}+\mathrm{H}]^{+}, 100\right)$. HRMS (ESI): calculated for $\mathrm{C}_{19} \mathrm{H}_{17} \mathrm{~N}_{2} \mathrm{O}_{4}\left([\mathrm{M}+\mathrm{H}]^{+}\right)$ 337.1183; found 337.1181. MW $=336.35 .{ }^{1} \mathrm{H}$ NMR spectrum and ${ }^{13} \mathrm{C}$ NMR spectrum of $(S)-17$ are provided in Figures S42-S43 in the Supporting Information. Chiral HPLC chromatograms of (S)-methyl ester are provided in Figures S69-S70 in the Supporting Information.

\subsection{2. (R)-3-(3a-hydroxy-6-methyl-4-oxo-2,3,3a,4-tetrahydro-1H-pyrrolo[2,3-b]quinolin-1-} yl)benzoic acid ((R)-17)

$(R)$-3'-carboxyblebbistatin $(R)-\mathbf{1 7}$ was synthesized from $(R)-3$ '-carbamoylblebbistatin $(R)-\mathbf{1 6}$ $\left(0.0500 \mathrm{~g}, 0.149 \mathrm{mmol}, 1\right.$ equiv). Evaporation in vacuo of the filtrate afforded $(R)-3^{\prime}-$ carboxyblebbistatin $(R)-17(0.0378 \mathrm{~g}, 75 \%)$ as a bright yellow powder. The enantiomeric excess of $(R)$-methyl ester (see general procedure above) was $91 \%$ as determined by chiral HPLC analysis. $\mathrm{mp} 250^{\circ} \mathrm{C}$. Chiral HPLC $(R)$-methyl ester: $t_{\mathrm{R}}((R)$-methyl ester $)=73.3 \mathrm{~min}$, $t_{\mathrm{R}}((S)$-methyl ester) $=62.7 \mathrm{~min}$ (Daicel Chiralpak IA column, acetonitrile/water (30:70), $\left.1.0 \mathrm{~mL} \min ^{-1}, 25^{\circ} \mathrm{C}\right) .[\alpha]^{25}{ }_{\mathrm{D}}=+172 \pm 5\left(c=0.11\right.$ in absolute ethanol). ${ }^{1} \mathrm{H}$ NMR $(400 \mathrm{MHz}$ 
$0.24 \mathrm{M} \mathrm{NaHCO}_{3}$ in $\left.\mathrm{D}_{2} \mathrm{O}\right): \delta=2.22(\mathrm{~s}, 3 \mathrm{H}), 2.30-2.38(\mathrm{~m}, 2 \mathrm{H}), 3.91-4.00(\mathrm{~m}, 1 \mathrm{H}), 4.05-4.16(\mathrm{~m}$, 1H), $6.96(\mathrm{~d}, J=8.4 \mathrm{~Hz}, 1 \mathrm{H}), 7.34$ (d, $J=8.4 \mathrm{~Hz}, 1 \mathrm{H}), 7.46$ (t, $J=7.9 \mathrm{~Hz}, 1 \mathrm{H}), 7.55$ (br. s, 1H), $7.68(\mathrm{~d}, J=7.9 \mathrm{~Hz}, 1 \mathrm{H}), 7.75$ (d, $J=7.9 \mathrm{~Hz}, 1 \mathrm{H}), 7.94$ (br. s, $1 \mathrm{H}) .{ }^{13} \mathrm{C} \mathrm{NMR}(100.6 \mathrm{MHz}$, $0.24 \mathrm{M} \mathrm{NaHCO}_{3}$ in $\left.\mathrm{D}_{2} \mathrm{O}\right): \delta=19.6,28.2,49.4,73.8,120.1,123.1,124.8,125.7,126.5,127.2$, 129.2, 133.9, 137.5, 138.3, 138.8, 148.8, 160.4, 166.0, 174.8, 196.5. MS (ESI): $m / z(\%)=336.6$ $\left([\mathrm{M}+\mathrm{H}]^{+}, 100\right)$. HRMS (ESI): calculated for $\mathrm{C}_{19} \mathrm{H}_{17} \mathrm{~N}_{2} \mathrm{O}_{4}\left([\mathrm{M}+\mathrm{H}]^{+}\right)$337.1183; found 337.1188. $\mathrm{MW}=336.35$. Chiral HPLC chromatogram of $(R)$-methyl ester is provided in Figure S71 in the Supporting Information.

\section{ATPase assay}

\subsection{Preparation of F-actin filaments stock solution}

Pre-formed rabbit skeletal muscle F-actin filaments (cat. \# AKF99) were purchased from Cytoskeleton, Inc. in lyophilized form $(1 \mathrm{mg})$. The protein was dissolved in $2.4 \mathrm{~mL}$ of Milli-Q water and gently mixed to a concentration of $0.4 \mathrm{mg} \mathrm{mL}^{-1}$. To allow filaments to dissociate from each other, this solution was incubated at room temperature for 10 minutes. Then, the filaments were aliquoted into $100 \mu \mathrm{L}$ samples, snap frozen in liquid nitrogen and stored at $-80{ }^{\circ} \mathrm{C}$. Compounds $(S)-\mathbf{1 - 3 , 1 3 , 1 6 , 1 7}$ were evaluated with the same batch of pre-formed rabbit skeletal muscle F-actin filaments.

\subsection{Preparation of myosin stock solution}

Full-length rabbit skeletal muscle myosin II protein (cat.\# MY02) was purchased from Cytoskeleton, Inc. in lyophilized form $(1 \mathrm{mg})$. The protein was dissolved in $100 \mu \mathrm{L}$ of Milli-Q water containing $1 \mathrm{mM}$ DTT and incubated on ice for 5 minutes to completely solubilize it to a

concentration of $10 \mathrm{mg} \mathrm{mL}^{-1}$. Care should be taken not to vortex the solution, in order to avoid protein denaturation caused by shear stress. Then, the myosin solution was further aliquoted into 
$10 \mu \mathrm{L}$ samples, snap frozen in liquid nitrogen and stored at $-80{ }^{\circ} \mathrm{C}$. Compounds $(S)-1-$ 3,13,16,17 were evaluated with the same batch of full-length rabbit skeletal muscle myosin II protein

\subsection{Preparation of ATP stock solution}

Adenosine 5'-triphosphate disodium salt (ATP, cat. \# BSA04) was purchased from Cytoskeleton, Inc. in lyophilized form $(1 \mathrm{mg})$. The ATP was reconstituted to $100 \mathrm{mM}$ with $1 \mathrm{~mL}$ of ice-cold $100 \mathrm{mM}$ Tris- $\mathrm{HCl} \mathrm{pH} 7.5$ and then aliquoted into $10 \mu \mathrm{L}$ samples, snap frozen in liquid nitrogen and stored at $-20{ }^{\circ} \mathrm{C}$. Compounds $(S)-\mathbf{1 - 3 , 1 3 , 1 6 , 1 7}$ were evaluated with the same batch of adenosine 5'-triphosphate disodium salt.

\subsection{ATPase assay}

Screening for inhibitors of rabbit skeletal muscle myosin II ATPase was performed in an ATPase end-point assay adapted from the method by Kodama et al. ${ }^{38}$ Incubation times and amounts of F-actin and myosin are based on a publication of Cheung et al ${ }^{39}$ As the linear range for inorganic phosphate detection of the assay extends from approximately $0.1 \mathrm{nmol}$ to $1.6 \mathrm{nmol}$ of inorganic phosphate, a total amount of $1.6 \mathrm{nmol}$ ATP was used. ${ }^{40}$

Prior to each assay, aliquoted samples of F-actin, myosin and ATP were defrosted rapidly in a $37^{\circ} \mathrm{C}$ water bath and further dilutions were made: myosin was diluted to $33 \mu \mathrm{g} \mathrm{mL} L^{-1}$ with icecold reaction buffer (15 mM Tris- $\mathrm{HCl} \mathrm{pH} 7.5,25 \mathrm{mM} \mathrm{KCl}, 10 \mathrm{mM} \mathrm{MgCl} 2,0.1 \mathrm{mM}$ EGTA) and stored on ice, ATP was diluted to $0.04 \mathrm{mM}$ with ice-cold $15 \mathrm{mM}$ Tris- $\mathrm{HCl} \mathrm{pH} 7.5$ and stored on ice, F-actin was diluted to $133 \mu \mathrm{g} \mathrm{mL}^{-1}$ with reaction buffer and stored at room temperature.

Chemical compounds dissolved in DMSO $(1 \mu \mathrm{L})$ were transferred into each well of a 96-well plate. Then, $15 \mu \mathrm{L}$ of reaction buffer, $15 \mu \mathrm{L}$ of $133 \mu \mathrm{gL}^{-1}$ F-actin and $15 \mu \mathrm{L}$ of $33 \mu \mathrm{g} \mathrm{mL}^{-1}$ myosin were subsequently distributed in each well using a multichannel pipette. Afterwards, the 
ATP hydrolysis reaction was initiated by adding $15 \mu \mathrm{L}$ of $0.04 \mathrm{mM}$ ATP per well using a multichannel pipette and was then incubated for 1 hour at $37^{\circ} \mathrm{C}$. To measure the amount of inorganic phosphate $\left(\mathrm{P}_{i}\right)$ generated during the enzymatic hydrolysis of ATP, $139 \mu \mathrm{L}$ of development solution (CytoPhos ${ }^{\mathrm{TM}}$ reagent, cat. \# BK054 from Cytoskeleton) was added to each well using a multichannel pipette. After 20 minutes, the absorbance at $650 \mathrm{~nm}$ was measured in each assay well using a SpectraMax ${ }^{\circledR}$ Paradigm ${ }^{\circledR}$ Multi-Mode Microplate Reader. On each assay plate, two concentrations of $(S)-\mathbf{1}(2.25 \mu \mathrm{M}$ and $32.5 \mu \mathrm{M})$ were included as a positive control, and the resulting amount of inhibition was comparable over the different assay plates. All screenings were carried out twice $(\mathrm{N}=2)$.

\subsection{IC $_{50}$ determination}

Dose-response curves were generated using the SoftMax Pro v6.1 software. Data points representing the means \pm s.d. of at least three samples, were plotted on semi-log axes and a 4-parameter logistic curve, based on the following equation, was fitted to the means.

$$
y=A+\frac{B-A}{1+\left(\frac{x}{C}\right)^{D}}
$$

Here, y represents the ATPase activity of rabbit skeletal muscle myosin II (\%) and $\mathrm{x}$ corresponds to the compound concentration $(\mu \mathrm{M})$. A is the ATPase activity corresponding to the asymptote at high compound concentrations (\%), B is the ATPase activity corresponding to the asymptote at low compound concentrations (\%), C represents the compound concentration corresponding to the midpoint between $\mathrm{A}$ and $\mathrm{B}(\mu \mathrm{M})$ (i.e. $\mathrm{IC}_{50}$ value), and $\mathrm{D}$ describes how rapidly the curve makes its transition from the asymptotes in the center of the curve.

\section{Determination of aqueous solubility}

The aqueous solubility was determined by Eurofins Panlabs. 
Compounds were added to a PBS pH 7.4 buffer as a $10 \mathrm{mM}$ dimethyl sulfoxide (DMSO) solution and were incubated at room temperature while agitating the suspension. DMSO and compound concentrations were $2 \%(\mathrm{v} / \mathrm{v})$ and $200 \mu \mathrm{M}$, respectively. After 24 hours, the suspension was centrifuged and filtered through a $0.2 \mu \mathrm{M}$ filter membrane. Compound concentrations in the buffer sample were determined by HPLC. Absorption spectra $(230 \mathrm{~nm})$ were recorded and the concentration of the dissolved compound was determined by comparing the peak area of the principal peak in the buffer sample with the peak area of the corresponding peak in a calibration standard $(200 \mu \mathrm{M})$ containing organic solvent (methanol/water (60:40)). The experiments were performed in duplicate.

\section{Cell culture}

The MCF-7/6 human breast carcinoma cell line was kindly provided by Dr. H. Rochefort (Unité d'Endocrinologie Cellulaire et Moléculaire, Montpellier, France). These cells were originally isolated from a pleural effusion of a breast adenocarcinoma ${ }^{41}$ Cells were cultured in a DMEM/Ham's F-12 (1:1) medium supplemented with $100 \mathrm{IU} \mathrm{mL}^{-1}$ penicillin (Gibco, Merelbeke, Belgium), $100 \mu \mathrm{g} \mathrm{mL}^{-1}$ streptomycin (Gibco, Merelbeke, Belgium) and 10\% fetal bovine serum at $37{ }^{\circ} \mathrm{C}$ in a saturated atmosphere with $10 \% \mathrm{CO}_{2}$. Tests for mycoplasma contamination are conducted monthly.

\section{Microscopic imaging of fluorescence}

MCF-7/6 human breast carcinoma cells $(500 \mu \mathrm{L})$ were seeded at a density of 50000 cells/well in a 24-well plate. $24 \mathrm{~h}$ after seeding, cells were treated with $500 \mu \mathrm{L}$ of different concentrations of test compounds or with DMSO as a solvent control (in threefold, final concentrations were $5 \mu \mathrm{M}$ or $50 \mu \mathrm{M}, 0.1 \% \mathrm{DMSO})$. After $24 \mathrm{~h}$ of incubation, bright field images and fluorescence 
images (488 nm excitation, GFP) were acquired on a Zeiss Axiovert 200M fluorescence microscope using a $20 \times$ objective.

\section{Fluorescence measurements}

Fluorescence measurements were performed using an Edinburgh Instruments F900 Fluorescence Spectrometer equipped with a $450 \mathrm{~W}$ Xenon Lamp. Compounds were dissolved in methanol and further diluted with phosphate buffered saline (PBS) to obtain a final concentration of $20 \mu \mathrm{M}$. The amount of methanol was maintained at a constant concentration of $2.67 \%(\mathrm{v} / \mathrm{v})$ in all samples. For all compounds, emission spectra were recorded after excitation at a wavelength of $365 \mathrm{~nm}$ and $488 \mathrm{~nm}$ (excitation bandwidth $=5 \mathrm{~nm}$, emission bandwidth $=1 \mathrm{~nm}$, dwell time $=$ $0.5 \mathrm{sec})$. A different sample was used for each wavelength. All compound emission spectra were corrected for the Raman lines of the solvent mixture by subtracting the emission spectrum of the solvent blank.

\section{SUPPORTING INFORMATION}

Synthetic protocols and compound characterization of compounds $4 \mathbf{b}, \mathbf{4 c}, \mathbf{S 5}, \mathbf{6 a}-\mathbf{d}, \mathbf{1 0}, \mathbf{7}, \mathbf{8 a}-\mathbf{d}$ and 9a-d; X-ray crystallographic data of $(S)-2$ and $(R)-2 ;{ }^{1} \mathrm{H}$ NMR spectra and ${ }^{13} \mathrm{C}$ NMR spectra; chiral HPLC chromatograms; additional data relating to ATPase assay and microscopic imaging of fluorescence.

\section{ACKNOWLEDGMENT}

S.V. is indebted to Ghent University (BOF) for financial support. B.I.R. and K.V.H. thank the Research Fund Flanders (FWO-Vlaanderen) for financial support. K.V.H. thanks the Hercules Foundation (project AUGE/11/029 “3D-SPACE: 3D Structural Platform Aiming for Chemical 
Excellence") for funding. R.V.D. thanks the Hercules Foundation (project AUGE/09/024 “Advanced Luminescence Setup") for funding. Glenn Wagemans is acknowledged for his contribution to the experimental work. The authors thank Nicola Piens for helpful discussions during the preparation of the text.

\section{REFERENCES}

1. H. L. Sweeney and A. Houdusse, Annu. Rev. Biophys., 2010, 39, 539-557.

2. L. M. Coluccio, Myosins: A superfamily of molecular motors, Springer, Netherlands, 2008.

3. M. Vicente-Manzanares, X. Ma, R. S. Adelstein and A. R. Horwitz, Nat. Rev. Mol. Cell. Biol., 2009, 10, 778-790.

4. L. M. Bond, D. A. Tumbarello, J. Kendrick-Jones and F. Buss, Future Med. Chem., 2012, 5, 41-52.

5. J. Limouze, A. F. Straight, T. Mitchison and J. R. Sellers, J. Muscle Res. Cell M., 2004, 25, 337-341.

6. A. Cheung, N. J. Westwood, I. Chen, T. J. Mitchison and A. F. Straight, Mol. Biol. Cell, 2001, 12 (Supplement), 271A-271A.

7. L. Derycke, C. Stove, A.-S. Vercoutter-Edouart, O. De Wever, L. Dollé, N. Colpaert, H. Depypere, J.-C. Michalski and M. Bracke, Int. J. Dev. Biol., 2011, 55, 835-840.

8. M. S. Duxbury, S. W. Ashley and E. E. Whang, Biochem. Biophys. Res. Commun., 2004, 313, 992-997.

9. V. Betapudi, L. S. Licate and T. T. Egelhoff, Cancer Res., 2006, 66, 4725-4733.

10. S. Ivkovic, C. Beadle, S. Noticewala, S. C. Massey, K. R. Swanson, L. N. Toro, A. R. Bresnick, P. Canoll and S. S. Rosenfeld, Mol. Biol. Cell, 2012, 23, 533-542.

11. M. J. Lehmann, N. M. Sherer, C. B. Marks, M. Pypaert and W. Mothes, J. Cell Biol., 2005, 170, 317-325.

12. M. Kumakura, A. Kawaguchi and K. Nagata, Virology, 2015, 476, 141-150.

13. J. Gao, S. Xiao, Y. Xiao, X. Wang, C. Zhang, Q. Zhao, Y. Nan, B. Huang, H. Liu, N. Liu, J. Lv, T. Du, Y. Sun, Y. Mu, G. Wang, S. F. Syed, G. Zhang, J. A. Hiscox, I. Goodfellow and E.-M. Zhou, Sci. Rep., 2016, 6, 25120. 
14. M. Lum and R. Morona, Pathog. Dis., 2014, 72, 174-187.

15. M. Zhang and P. V. Rao, Invest. Ophthalmol. Vis. Sci., 2005, 46, 4130-4138.

16. J. Si, Y. Ge, S. Zhuang and R. Gong, Lab. Invest., 2010, 90, 448-458.

17. E. J. Young, A. M. Blouin, S. B. Briggs, S. E. Sillivan, L. Lin, M. D. Cameron, G. Rumbaugh and C. A. Miller, Mol. Psychiatry, 2016, 21, 615-623.

18. J. Kolega, Biochem. Biophys. Res. Commun., 2004, 320, 1020-1025.

19. B. Ramamurthy, C. M. Yengo, A. F. Straight, T. J. Mitchison and H. L. Sweeney, Biochemistry, 2004, 43, 14832-14839.

20. C. Lucas-Lopez, S. Patterson, T. Blum, A. F. Straight, J. Toth, A. M. Z. Slawin, T. J. Mitchison, J. R. Sellers and N. J. Westwood, Eur. J. Org. Chem., 2005, 2005, 1736-1740.

21. T. Sakamoto, J. Limouze, C. A. Combs, A. F. Straight and J. R. Sellers, Biochemistry, 2005, 44, 584-588.

22. A. Mikulich, S. Kavaliauskiene and P. Juzenas, Biochim. Biophys. Acta, Gen. Subj., 2012, 1820, 870-877.

23. M. Képiró, B. H. Várkuti, L. Végner, G. Vörös, G. Hegyi, M. Varga and A. MálnásiCsizmadia, Angew. Chem., Int. Ed., 2014, 53, 8211-8215.

24. M. Képiró, B. H. Várkuti, A. Bodor, G. Hegyi, L. Drahos, M. Kovács and A. MálnásiCsizmadia, Proc. Natl. Acad. Sci. U. S. A., 2012, 109, 9402-9407.

25. L. M. Swift, H. Asfour, N. G. Posnack, A. Arutunyan, M. W. Kay and N. Sarvazyan, Pflugers Arch. Eur. J. Physiol., 2012, 464, 503-512.

26. V. V. Fedorov, I. T. Lozinsky, E. A. Sosunov, E. P. Anyukhovsky, M. R. Rosen, C. W. Balke and I. R. Efimov, Heart Rhythm, 2007, 4, 619-626.

27. K. Wong, A. Van Keymeulen and H. R. Bourne, J. Cell Biol., 2007, 179, 1141-1148.

28. Y. Shiba, S. Fernandes, W.-Z. Zhu, D. Filice, V. Muskheli, J. Kim, N. J. Palpant, J. Gantz, K. W. Moyes, H. Reinecke, B. Van Biber, T. Dardas, J. L. Mignone, A. Izawa, R. Hanna, M. Viswanathan, J. D. Gold, M. I. Kotlikoff, N. Sarvazyan, M. W. Kay, C. E. Murry and M. A. Laflamme, Nature, 2012, 489, 322-325.

29. A. F. Straight, A. Cheung, J. Limouze, I. Chen, N. J. Westwood, J. R. Sellers and T. J. Mitchison, Science, 2003, 299, 1743-1747.

30. B. H. Várkuti, M. Képiró, I. Á. Horváth, L. Végner, S. Ráti, Á. Zsigmond, G. Hegyi, Z. Lenkei, M. Varga and A. Málnási-Csizmadia, Sci. Rep., 2016, 6, 26141. 
31. B. S. Pedersen, S. Scheibye, N. H. Nilsson and S. O. Lawesson, B. Soc. Chim. Belg., 1978, 87, 223-228.

32. Y. Dou, P. Arlock and A. Arner, Am. J. Physiol. Cell Physiol., 2007, 293, C1148-C1153.

33. D. R. Vutukuri, P. Bharathi, Z. Yu, K. Rajasekaran, M.-H. Tran and S. Thayumanavan, J. Org. Chem., 2003, 68, 1146-1149.

34. J. K. Belardi and G. C. Micalizio, Angew. Chem., Int. Ed., 2008, 47, 4005-4008.

35. K. W. Fowler, D. Huan, E. A. Kesicki, H. C. Ooi, A. R. Oliver, F. Rua and J. Treiberg, WO 2005/113556 A1, 2005.

36. Center For Disease Control and Prevention. Diazomethane. http://www.cdc.gov/niosh/ipcsneng/neng1256.html, (accessed February 2016).

37. International Programme on Chemical Safety. Diazomethane. http://www.inchem.org/documents/icsc/icsc/eics1256.htm, (accessed February 2016).

38. T. Kodama, K. Fukui and K. Kometani, J. Biochem., 1986, 99, 1465-1472.

39. A. Cheung, J. A. Dantzig, S. Hollingworth, S. M. Baylor, Y. E. Goldman, T. J. Mitchison and A. F. Straight, Nat. Cell Biol., 2002, 4, 83-88.

40. The $0.4 \mathrm{mg} \mathrm{mL}^{-1}$ solution of pre-formed rabbit skeletal muscle F-actin filaments (cat. \# AKF99) from Cytoskeleton, Inc. already contains $0.2 \mathrm{mM} \mathrm{ATP.}$

41. H. D. Soule, J. Vazquez, A. Long, S. Albert and M. Brennan, J. Natl. Cancer Inst., 1973, 51, 1409-1416. 